\title{
The Hydrolysis of Phosphinates and Phosphonates: A Review
}

\author{
Nikoletta Harsági and György Keglevich * (D) \\ Department of Organic Chemistry and Technology, Budapest University of Technology and Economics, \\ 1521 Budapest, Hungary; harsagi.nikoletta@vbk.bme.hu \\ * Correspondence: keglevich.gyorgy@vbk.bme.hu; Tel.: +36-1-463-1111 (ext. 5883)
}

check for

updates

Citation: Harsági, N.; Keglevich, G. The Hydrolysis of Phosphinates and Phosphonates: A Review. Molecules 2021, 26, 2840. https://doi.org/ $10.3390 /$ molecules 26102840

Academic Editor: Georg Manolikakes

Received: 19 April 2021

Accepted: 6 May 2021

Published: 11 May 2021

Publisher's Note: MDPI stays neutral with regard to jurisdictional claims in published maps and institutional affiliations.

Copyright: (c) 2021 by the authors. Licensee MDPI, Basel, Switzerland. This article is an open access article distributed under the terms and conditions of the Creative Commons Attribution (CC BY) license (https:// creativecommons.org/licenses/by/ $4.0 /)$.

\begin{abstract}
Phosphinic and phosphonic acids are useful intermediates and biologically active compounds which may be prepared from their esters, phosphinates and phosphonates, respectively, by hydrolysis or dealkylation. The hydrolysis may take place both under acidic and basic conditions, but the C-O bond may also be cleaved by trimethylsilyl halides. The hydrolysis of $P$-esters is a challenging task because, in most cases, the optimized reaction conditions have not yet been explored. Despite the importance of the hydrolysis of P-esters, this field has not yet been fully surveyed. In order to fill this gap, examples of acidic and alkaline hydrolysis, as well as the dealkylation of phosphinates and phosphonates, are summarized in this review.
\end{abstract}

Keywords: hydrolysis; dealkylation; phosphinates; phosphonates; $P$-acids

\section{Introduction}

Phosphinic and phosphonic acids are of great importance due to their biological activity (Figure 1) [1]. Most of them are known as antibacterial agents [2,3]. Multidrugresistant (MDR) and extensively drug-resistant (XDR) pathogens may cause major problems in the treatment of bacterial infections. However, Fosfomycin has remained active against both Gram-positive and Gram-negative MDR and XDR bacteria [2]. Acyclic nucleoside phosphonic derivatives like Cidofovir, Adefovir and Tenofovir play an important role in the treatment of DNA virus and retrovirus infections [4]. Some $P$-esters have also been shown to be effective against Hepatitis $C$ and Influenza A virus [5], and some are known as glutamate and GABA-based CNS therapeutics [5-7]. Glutamate is a main excitatory neurotransmitter, so agonists of the metabotropic glutamate receptor can be new therapeutic targets for brain disorders (schizophrenia, Parkinson's disease, pain). GABA is a main inhibitory neurotransmitter which is responsible for neurological disorders (epilepsy, anxiety disorders). Dronates are known to increase the mineral density in bones $[8,9]$. Moreover, $P$-esters include antimalarial agents $[5,10,11]$, anticancer agents $[5,12-14]$ and angiotensin-converting enzyme (ACE) inhibitors [15]. In addition, the use of $P$-acids as herbicides (glyphosate, glyfosinate) [5,16] is not negligible either. Phosphinic acids are of interest due to their ability to inhibit metalloproteases [17]. Methylphosphonic acid is known as a flame retardant [18]. During the preparation of these compounds, an esterprotecting group is introduced into the molecule, and the hydrolysis of the ester group is necessary in the final steps.

For a long time, water was used as the solvent only in hydrolyses. Despite its favorable properties (cheap, available, safe and "green"), water could not spread as a general solvent. This is due to the low solubility of organic substrates. The application of co-solvents, such as alcohols, DMF, acetone and acetonitrile is a good possibility. However, the regeneration of water or water-solvent mixtures is not easy.

Despite their great importance, the hydrolysis of $P$-esters has not been adequately studied. Often, unoptimized routine hydrolyses were described or the kinetics of these processes were studied. In most cases, the esters were reacted under harsh conditions with a large excess of concentrated acid, and often the applied reaction time was longer than 
necessary. Hydrolyses can be catalyzed by acids and bases as well (Scheme 1) [19]. Acidic hydrolyses can be catalyzed both by mineral and Lewis acids [20]. Mineral acids are mostly hydrogen halides [21], e.g., hydrochloric acid [22-27], but hydrobromic acid [28-32] proved to be more efficient. Despite this, the application of hydrochloric acid was widespread. The hydrolyses were generally performed at around $100{ }^{\circ} \mathrm{C}$ with longer reaction times [20]. There are also examples when trifluoroacetic acid (TFA) $[17,33,34]$ or $\mathrm{HClO}_{4}[35,36]$ was used to catalyze the hydrolyses. Sodium hydroxide is the most commonly used reagent in alkaline hydrolysis [37-41], but there are also examples of the application of $\mathrm{KOH}$ [42], $\mathrm{LiOH}\left[40,43\right.$ ] and $\mathrm{NaHCO}_{3}$ [44]. The alkaline hydrolysis is irreversible and less corrosive, but alkali-sensitive molecules can be damaged. A further disadvantage is that the basecatalyzed hydrolyses take place in two steps: first, the sodium-salt of the acid is formed, then the corresponding acid is liberated. In the case of acid catalysis, the $P$-acids are obtained directly.

Antibacterial agent<smiles>C[C@@H]1O[C@@H]1P(=O)(O)O</smiles>

Against HIV infections<smiles>Nc1ccn(CC(CO)COP(=O)(O)O)c(=O)n1</smiles>

Cidofovir<smiles>Nc1ncnc2c1ncn2CCOCP(=O)(O)O</smiles>

Adefovir<smiles>C[C@H](Cn1cnc2c(N)ncnc21)OCP(=O)(O)O</smiles>

Tenofovir
GABA $_{C_{\rho}}$ receptor antagonists<smiles>NCC1CCP(=O)(O)C1</smiles>

3-AMOHP<smiles>N=C(N)NCC1CCP(=O)(O)C1</smiles>

3-GOHP
Increase bone mineral density<smiles>NCCCC(P(=O)(O)O)(P(=O)(O)O)P(=O)(O)O</smiles>

Alendronate

\section{Antimalarial agent}

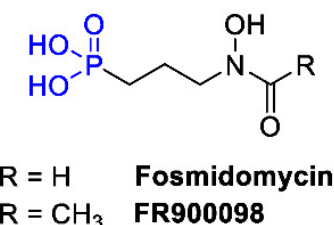

\section{Herbicides}<smiles>O=C(O)CNCP(=O)(O)O</smiles>

Glyfosate<smiles>CP(=O)(O)CCC(N)C(=O)O</smiles>

Glyfosinate

Figure 1. A few biologically active phosphinic and phosphonic acids.

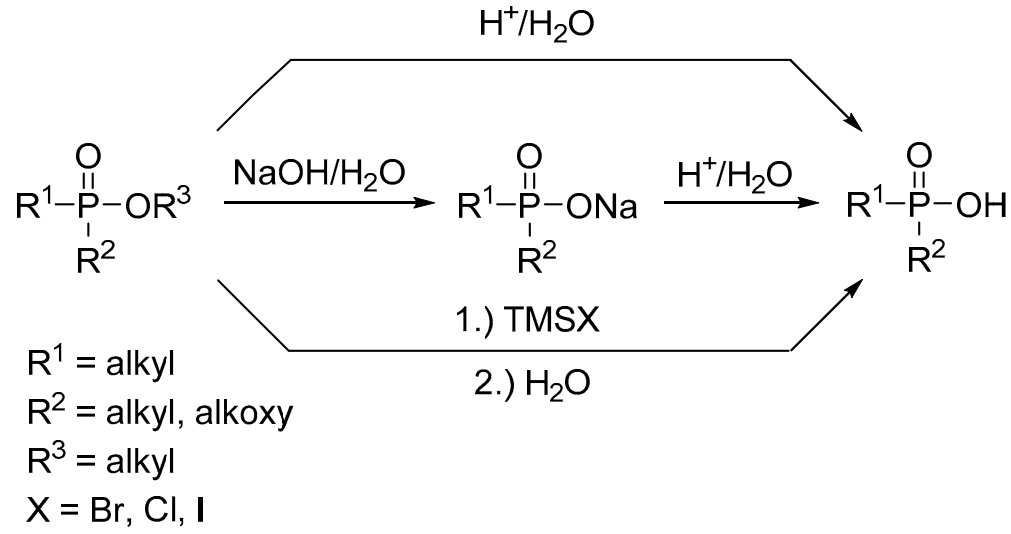

Scheme 1. The most commonly used strategies to prepare $P$-acids. 
During hydrolysis, a nucleophilic attack occurs on the phosphorus atom of the $\mathrm{P}=\mathrm{O}$ unit [45]. In most of the cases, the P-O bond is cleaved during the acid- and base-catalyzed hydrolyses. The rate of hydrolysis may be influenced by the $\mathrm{pH}[35,36]$ and by the ionic strength of the medium, but the type of ion added to the system is also decisive.

There are a few cases when the desired $P$-acid is not prepared by hydrolysis, but by the cleavage of the C-O bond, which is possible by pyrolysis [46] or in reaction with trimethylsilyl halides (Scheme 1) [47-52], boron tribromide [53], or various amines [54-56]. Dealkylations with trimethylsilyl halides takes place under mild conditions, such that they can also be used for the hydrolysis of esters in which instances strong acidic or alkaline treatments cannot be applied, such as in the cases of nitriles, vinyl ethers and acetals [57-59]. In addition, various enzyme-catalyzed [60-72] hydrolyses have also been elaborated, and there are examples for the application of special catalysts and metal ions as well [73-77].

It is important to mention that $P$-acids can also be prepared indirectly (Scheme 2). In this case, the ester (1) is converted to the corresponding acid chloride (2), which is a more reactive derivative, and can react with water at room temperature $[78,79]$. This method cannot be considered as a good solution from the point of view of its number of steps and atomic efficiency.<smiles>[R]P1(=O)C=C(C)C(Cl)=CC1</smiles>

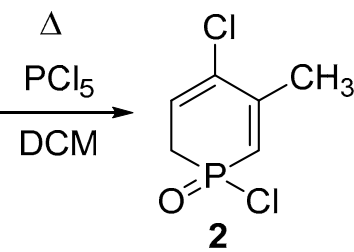<smiles>CC1=CP(=O)(O)CC=C1Cl</smiles>

Scheme 2. Indirect preparation of a ring $P$-acid.

In this survey, we discuss the acidic hydrolysis of phosphinates and phosphonates. This is followed by the presentation of the alkaline and basic hydrolysis of phosphinates and that of phosphonates. The reactivity of the different substrates, the effect of the substituents, and their green chemical aspects are the focus. Last but not least, the conversion of $P$-esters to acids by dealkylation is summarized.

\section{Acidic Hydrolysis of Phosphinates and Phosphonates}

\subsection{Acidic Hydrolysis of Phosphinates}

In a paper published in 1973, Cook et al. compared the acid-catalyzed hydrolysis of methyl dialkylphosphinates (4) with base-catalyzed examples (Scheme 3) [80]. It was concluded that polar and steric effects hardly influence the acid-catalyzed hydrolysis compared to the base-catalyzed version. In a subsequent publication, they demonstrated that the hydrolysis of the methyl esters proceeds by the rarely occurring $\mathrm{A}_{\mathrm{Al}} 2$ mechanism (water is involved and C-O bond cleavage occurs) [81]. The major routes involve the $\mathrm{A}_{\mathrm{Ac}} 2$ mechanism (water is involved and $\mathrm{P}-\mathrm{O}$ bond cleavage occurs) and the $\mathrm{A}_{\mathrm{Al}} 1$ mechanism (water is not involved in the rate-determining step, and a C-O bond cleavage occurs) [82]. The mechanistic study was extended to the hydrolysis of additional esters $[82,83]$.

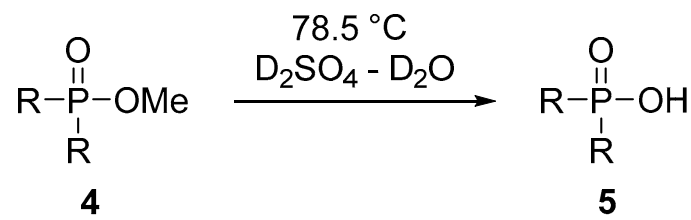

$\mathrm{R}=\mathrm{Me}, \mathrm{Et},{ }^{\mathrm{i}} \mathrm{Pr}$

Scheme 3. Acid-catalyzed hydrolysis of methyl dialkylphosphinates (4).

Bunnett et al. studied the hydrolysis of different methyl methyl-arylphosphinates (6) at various $\mathrm{HClO}_{4}$ concentrations $(1-9 \mathrm{M})$ and temperatures $\left(67.2,95.1,107.6{ }^{\circ} \mathrm{C}\right)$ 
(Scheme 4) [35]. The hydrolysis was found to be optimal at a 6-7 M acid concentration, above which the reaction became slightly slower.

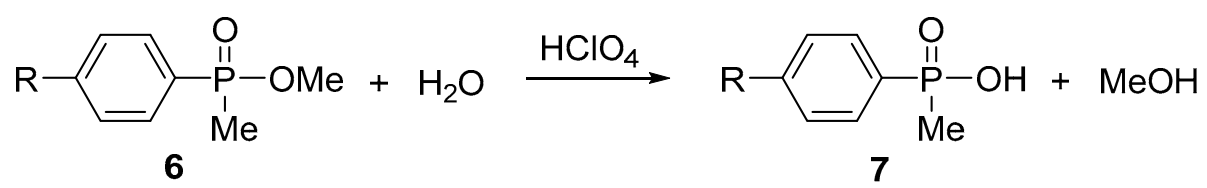

$$
\mathrm{R}=\mathrm{H}, \mathrm{Me}, \mathrm{Cl}
$$

Scheme 4. Hydrolysis of different methyl methyl-arylphosphinates (6) with $\mathrm{HClO}_{4}$.

The hydrolysis of $p$-nitrophenyl diphenylphosphinate (8) under acid catalysis was also studied (Scheme 5) [36]. The rate constant was determined at different acid concentrations in a dioxane-water mixture to ensure homogeneity. There is a maximum rate at $1.5 \mathrm{M} \mathrm{HClO}_{4}$. In more concentrated solutions, the acidic inhibition of the hydrolysis was observed.<smiles>CC(C(=O)O)C(=O)Oc1ccc([N+](=O)[O-])cc1</smiles>

Scheme 5. Hydrolysis of $p$-nitrophenyl diphenylphosphinate (8) under acid catalysis.

There were cases when alkaline hydrolysis proved to be slow at room temperature, but at higher temperatures it was too harsh for sensitive substrates. In these cases, acidic hydrolysis is more favorable. A good example is the acidic hydrolysis of a $\beta$-carboxamidosubstituted phosphinic acid ester (10), as this is a rapid and gentle way to provide the corresponding phosphinic acid (11) quantitatively (Scheme 6) [17]. In this particular case, trifluoroacetic acid was the catalyst in an aqueous medium.<smiles>CC(C)C[C@H](CNCc1ccccc1)C(=O)P(C)(=O)Cc1ccccc1</smiles>

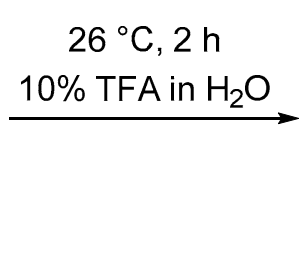<smiles>CC(C)C[C@H](CP(=O)(O)Cc1ccccc1)C(=O)NCc1ccccc1</smiles>

Scheme 6. Hydrolysis of $\beta$-carboxamido-substituted phosphinate (10).

In the following example, the preparation of bis(3-aminophenyl)phosphinic acid (13) using hydrochloric acid as the catalyst in ethanol is demonstrated (Scheme 7) [84]. The starting bis(aniline) derivative was obtained from the bis-nitro compound by reduction. The exact conditions were not reported.

$\alpha$-Aminophosphinic acids and their derivatives form an important group due to their synthetic and medicinal interest. The hydrolysis of phosphinates 14 using $c c . \mathrm{HCl}$ (Scheme 8) [85] or $\mathrm{HBr} / \mathrm{AcOH}$ [86] provided optically active $\alpha$-aminophosphinic acids (15).

The hydrolysis of $\beta$-aminophosphinates (16) was performed using hydrochloric acid at the boiling point (Scheme 9) [87]. To $3 \mathrm{~g}$ substrate, $20 \mathrm{~mL} \mathrm{cc}$. $\mathrm{HCl}$ was added, and the mixture was stirred at reflux for 1.5-4 $\mathrm{h}$.

The hydrolysis of a $\mathrm{GABA}_{\mathrm{B}}$ antagonist ethyl phosphinate (18) was performed by applying $c c$. $\mathrm{HCl}$ at $100{ }^{\circ} \mathrm{C}$ for $24 \mathrm{~h}$ (Scheme 10) [6]. 


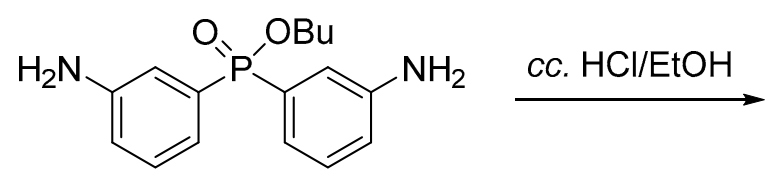

12<smiles>[NH3+]c1cccc(P(=O)(O)c2cccc([NH3+])c2)c1</smiles>

13

$75 \%$

Scheme 7. Preparation of bis(3-aminophenyl) (13) phosphinic acid using hydrochloric acid as the catalyst.<smiles>[X]c1ccc(C(N)P(=O)(OCC)c2ccccc2)cc1</smiles>

$$
\Delta, 3 \mathrm{~h}
$$

cc. $\mathrm{HCl}$

14<smiles>[Y]c1ccc([C@H](N)P(=O)(O)P(=O)([SnH])c2ccccc2)cc1</smiles>

$82-93 \%$

$\mathrm{Y}=\mathrm{H}, 4-\mathrm{NO}_{2}$, 4-Cl, 4-Br, 4-F, 4-Me, 4-OMe

Scheme 8. Synthesis of $\alpha$-aminophosphinic acid (15).<smiles>[R1]C([R])CP(=O)(COCC)OCC</smiles>

$\mathrm{R}^{1}=\mathrm{H}, \mathrm{C}(\mathrm{O}) \mathrm{Me}$

$\mathrm{R}^{2}=\mathrm{H}, \mathrm{COOH}$

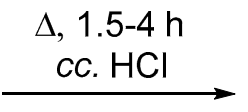<smiles>[R]C(N)C[PH](=O)O</smiles>

20-56\%

Scheme 9. Hydrolysis of $\beta$-aminophosphinates (16).

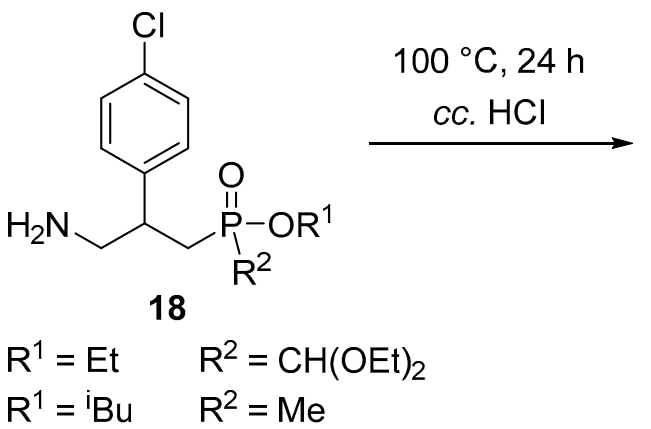<smiles>[R]P(=O)(O)CC(CN)c1ccc(Cl)cc1</smiles>

$57-60 \%$

Scheme 10. Preparation of $G_{A B A}$ antagonist phosphinic acid (19) using hydrochloric acid.

Natchev and co-workers investigated the acidic and enzymatic hydrolysis of phosphoryl analogues of glycine [61]. While the acidic hydrolysis was performed using 15-20\% acid at reflux for 6-7 h to afford the corresponding phosphinic acid (21) at a yield of $94 \%$, the enzymatic variation carried out using $\alpha$-chymotrypsin under milder conditions $\left(37^{\circ} \mathrm{C}\right.$ for $6 \mathrm{~h}$ ) gave the acid quantitatively (Scheme 11).

During the preparation of $\beta$-functionalized hydroxymethylphosphinic acid derivatives (22), double hydrolysis took place at a temperature of $80{ }^{\circ} \mathrm{C}$ in $3 \mathrm{~h}$. In this case, 15 equivalents of $35 \%$ hydrochloric acid were used, which may be regarded as a large excess (Scheme 12) [88]. 
$\Delta, 6-7 \mathrm{~h}$

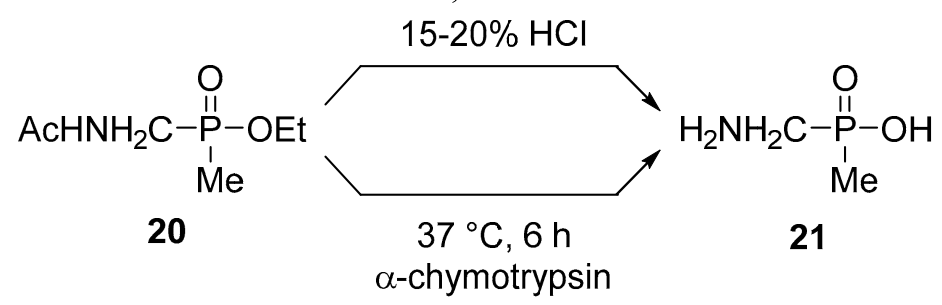

Scheme 11. Acidic and enzymatic hydrolysis of a glycine analogue phosphinate (20).

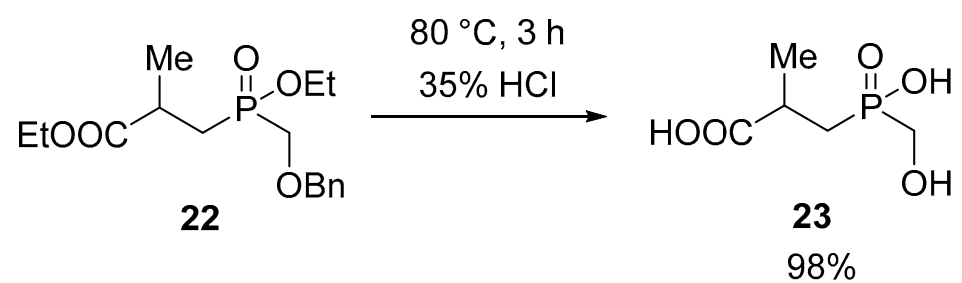

Scheme 12. Preparation of a $\beta$-functionalized hydroxymethylphosphinic acid derivative (23).

Dennis and co-workers investigated the hydrolyses of different saturated and unsaturated cyclic phosphinates, along with their open chain analogues under acidic conditions (Figure 2) [89]. They compared the rate constants of similar derivatives, and found the following ratios: $\mathrm{k}_{\mathrm{A}} / \mathrm{k}_{\mathrm{D}} 1 ; \mathrm{k}_{\mathrm{B}} / \mathrm{k}_{\mathrm{E}} 1 ; \mathrm{k}_{\mathrm{C}} / \mathrm{k}_{\mathrm{F}} 3$. These results are surprising, as the hydrolysis of cyclic phosphonates and phosphates is generally much faster than that of their open-chain analogues.<smiles>CCOP1(=O)CCCC1</smiles>

A<smiles>CCOP(=O)(CC)CC</smiles>

D<smiles>CCOP1(=O)C=CCC1</smiles>

B<smiles>C=CP(=O)(O)CC</smiles>

E<smiles>CCOP1(=O)CC=CC1</smiles>

C<smiles>C=CCP(=O)(CC)OCC</smiles>

$\mathbf{F}$

Figure 2. Cyclic and acyclic phosphinate pairs studied.

The most general procedure to prepare phosphinic acids from their esters involves the use of a concentrated $\mathrm{HCl}$ solution at reflux. Different $\mathrm{GABA}_{\mathrm{C} \rho}$ antagonists, such as 1-hydroxyphospholane oxide 25 , were prepared by hydrolysis with hydrochloric acid [7]. To $0.50 \mathrm{mmol}$ cyclic ester $\mathbf{2 4}, 2 \mathrm{~mL} \mathrm{HCl}$ was added, and the mixture was refluxed for $5 \mathrm{~h}$ (Scheme 13).

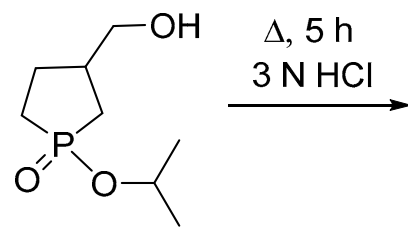

24<smiles>O=P1(O)CCC(CO)C1</smiles>

25

$68 \%$

Scheme 13. Preparation of $\mathrm{GABA}_{\mathrm{C} \rho}$ antagonist 25 in the presence of aqueous $\mathrm{HCl}$ acid.

In our research group, the hydrolysis of a series of cyclic phosphinates (26) was investigated (Scheme 14) [90]. First, we wished to explore the optimal reaction conditions, 
including the reaction time, acid concentration, and the necessary amount of hydrochloric acid. It was found that for the hydrolysis of $1.9 \mathrm{mmol}$ phosphinate (26), the use of $0.5 \mathrm{~mL}$ $c c$. $\mathrm{HCl}$ and $1 \mathrm{~mL}$ water was optimal, along with a reaction time of $6 \mathrm{~h}$. Interestingly, in the case of the hydrolysis of unsaturated cyclic phosphinates, these compounds underwent isomerization as well. The results are summarized in Table 1.<smiles>[R]P1(=O)CCCCCC1</smiles>

26

$\mathrm{R}=\mathrm{Me}, \mathrm{Et}$

$\Delta$

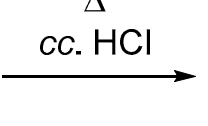

27<smiles>O=P1(O)CCCCCC1</smiles>

27<smiles>CC1=CCCC=C1C</smiles>

A

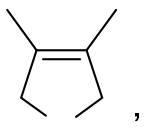

B

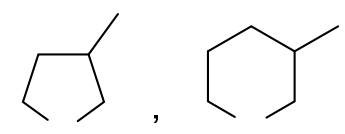

C

D

Scheme 14. Hydrolysis of saturated and unsaturated cyclic phosphinates (26).

Table 1. Experimental data of the hydrolysis of unsaturated and saturated cyclic phosphinates.

\begin{tabular}{|c|c|c|c|c|}
\hline \multirow{2}{*}{ Compound } & \multirow{2}{*}{$t(h)$} & \multicolumn{2}{|c|}{ Composition of Product (\%) } & \multirow{2}{*}{ Yield (\%) } \\
\hline & & 2-Phospholene & 3-Phospholene & \\
\hline & 3 & 79 & 21 & 85 \\
\hline & 6 & 90 & 10 & 84 \\
\hline & 6 & 21 & 73 & 86 \\
\hline & 8 & & & 82 \\
\hline & 10 & & . & 80 \\
\hline
\end{tabular}

After exploring the optimum conditions, the method was extended to the hydrolysis of other esters, and the kinetics were also investigated. Figure 3 demonstrates the order of reactivity observed under the above-mentioned conditions [90].<smiles></smiles>

Figure 3. Reactivity order for different cyclic phosphinate derivatives. 
The hydrolyses were also carried out under microwave (MW) conditions. In this case, $p$-toluenesulfonic acid (PTSA) was used as the catalyst in order to avoid the corrosion of the reactor (Scheme 15) [90]. It is important to note that due to the beneficial effect of MW irradiation, the reaction times were shorter than they were in the case of conventional heating.<smiles>[R]P1(=O)CC=C(C)C1</smiles>

26A

$\mathrm{R}=\mathrm{Me}, \mathrm{Et}$
MW

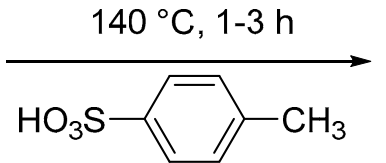

(3 equiv.)<smiles>[R]P1(=O)C=C(C)CC1</smiles>

28<smiles>CC1=CCP(=O)(O)[CH+]1</smiles>

27A<smiles>CC1=CP(=O)(O)CC1</smiles>

29

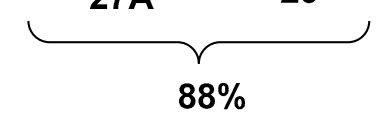

Scheme 15. MW-assisted hydrolysis of alkoxyphospholene oxides (26A) in the presence of PTSA.

The acidic hydrolysis of acyclic esters, such as diphenylphosphinates (30), was also studied under conventional heating and microwave irradiation (Scheme 16) [91]. The traditional hydrolysis was performed using three equivalents of diluted hydrochloric acid for 3-6.5 h. In the other series of experiments comprising MW-assisted hydrolyses, $p$-toluenesulfonic acid was used as the catalyst. The amount of the catalyst was decreased to 0.1 equivalents. At $160{ }^{\circ} \mathrm{C}$, complete hydrolysis occurred in $2-6.5 \mathrm{~h}$, and at $180{ }^{\circ} \mathrm{C}$ in $0.5-2 \mathrm{~h}$. The pseudo-first-order rate constants obtained are listed in Table 2.

$\Delta$

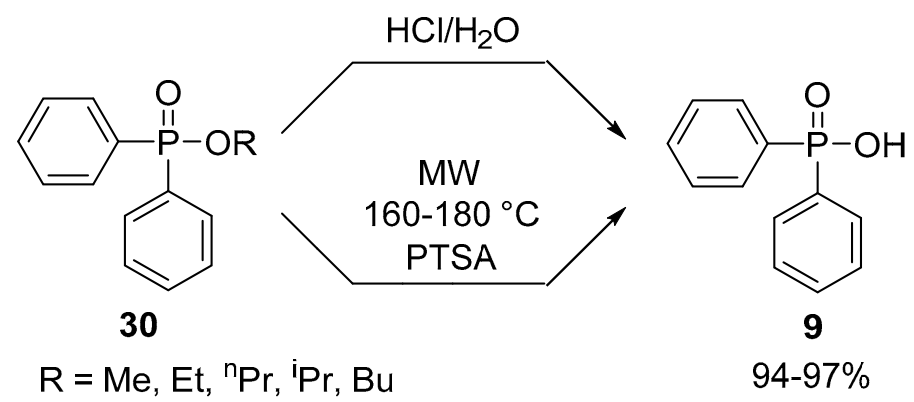

Scheme 16. Acidic hydrolysis of diphenylphosphinates (30) under conventional heating and MW irradiation.

Table 2. Pseudo-first-order rate constants $\left(\mathrm{k}_{\Delta}\right.$ and $\left.\mathrm{k}_{\mathrm{MW}}\right)$ obtained for the thermal HCl-catalyzed and MW-assisted PTSA-catalyzed hydrolyses.

\begin{tabular}{cccc}
\hline Entry & $\mathbf{R}$ & $\mathbf{k}_{\boldsymbol{\Delta}} \mathbf{( h}^{-\mathbf{1}} \mathbf{)}$ & $\mathbf{k}_{\mathbf{M W}} \mathbf{( \mathbf { h } ^ { - \mathbf { 1 } } )}$ \\
\hline 1 & $\mathrm{Me}$ & 1.36 & 1.52 \\
2 & $\mathrm{Et}$ & 0.62 & 0.86 \\
3 & $\mathrm{n} \operatorname{Pr}$ & 0.62 & - \\
4 & $\mathrm{i} \operatorname{Pr}$ & 1.60 & 1.92 \\
5 & $\mathrm{n} \mathrm{Bu}$ & 0.57 & - \\
\hline
\end{tabular}

\subsection{Acidic Hydrolysis of Phosphonates}

The hydrolysis of phosphonates is a widely applied method. Due to the two ester groups, these hydrolyses take place in two steps in a consecutive manner. Most often, the aqueous solution of hydrochloric acid was applied as the medium, and after the hydrolysis, the water was removed by distillation. Occasionally, $\mathrm{HBr}$ was also used in the hydrolysis of phosphonates [21]. 
Methylphosphonic acid (32), which is known as a flame retardant, may be prepared by the acidic hydrolysis of dimethyl methylphosphonate (31) (Scheme 17) [18].

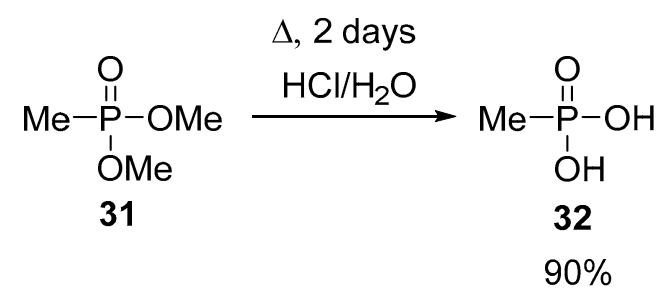

Scheme 17. Preparation of methylphosphonic acid (32) by acidic hydrolysis.

The effect of the alkyl group of dialkyl phosphonates was investigated in acid- and base-catalyzed hydrolyses. It was found that during acid catalysis, the isopropyl derivative was hydrolyzed faster than the methyl ester, but under basic conditions, the reaction of the methyl ester was 1000-fold faster than that of the isopropyl derivative [92].

Our research group investigated the preparation of arylphosphonic acids (34) by refluxing the corresponding phosphonates (33) with an excess (six equivalents) of hydrochloric acid for $12 \mathrm{~h}$ (Scheme 18) [93].<smiles>[R]c1cc(P(=O)(OCC)OCC)c([R])c([R])c1[R]</smiles>

33

$\mathrm{R}^{1}=\mathrm{H}, \mathrm{Me},{ }^{\mathrm{C}} \mathrm{Hex}, \mathrm{OCF}_{3}, \mathrm{CF}_{3}, \mathrm{OMe}, \mathrm{C}(\mathrm{O}) \mathrm{Me}, \mathrm{F}$ $\mathrm{R}^{2}=\mathrm{H}, \mathrm{F}$

$\mathrm{R}^{3}=\mathrm{H}, \mathrm{Me}, \mathrm{F}$

$\mathrm{R}^{4}=\mathrm{H}, \mathrm{F}$

Scheme 18. Acidic hydrolysis of dialkyl arylphosphonates (33).

Depending on the substituents, the phosphonic acids were obtained in yields of 71-93\% [93]. However, a reflux with concentrated hydrochloric acid for $12 \mathrm{~h}$ cannot be considered to be a "gentle" method.

We also studied the hydrolysis of various arylphosphonates (35): phenylphosphonates and their derivatives containing a 4-methyl or a 4-acetyl group in the phenyl ring. The reactions were carried out at the optimum conditions found for the hydrolysis of cyclic phosphinates (Scheme 19) [94]. In most of the cases, the reaction proceeded according to the $\mathrm{A}_{\mathrm{Ac}} 2$ mechanism, but in the case of the benzyl and isopropyl ester, the $\mathrm{A}_{\mathrm{Al}} 1$ mechanism was substantiated.

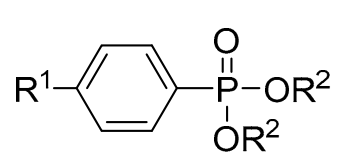

35
$\Delta$<smiles>OCO</smiles><smiles>[R]OP(=O)(O)c1ccc([R])cc1</smiles>

36

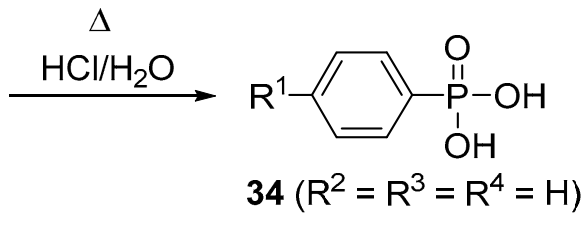

$80-99 \%$

$\mathrm{R}^{1}=\mathrm{H}, \mathrm{Me}, \mathrm{C}(\mathrm{O}) \mathrm{Me}$

$\mathrm{R}^{2}=\mathrm{Me}, \mathrm{Et},{ }^{\mathrm{i}} \mathrm{Pr}, \mathrm{Bn}$

Scheme 19. Acidic hydrolysis of dialkyl arylphosphonates (35) under the optimum conditions. 
The consecutive reaction steps were characterized by pseudo-first-order rate constants. One can see that the cleavage of the second P-OC bond was the slower process in each case, suggesting that the latter is the rate-determining step (Table 3).

Table 3. Pseudo-first-order rate constants $\left(\mathrm{k}_{\Delta}\right.$ and $\left.\mathrm{k}_{\mathrm{MW}}\right)$ obtained for the thermal HCl-catalyzed and MW-assisted PTSA-catalyzed hydrolyses.

\begin{tabular}{cccccc}
\hline $\mathbf{R}^{\mathbf{2}}$ & $\mathbf{R}^{\mathbf{1}}$ & $\left.\mathbf{k}_{\mathbf{1}} \mathbf{( h}^{-\mathbf{1}}\right)$ & $\left.\mathbf{k}_{\mathbf{2}} \mathbf{( h}^{-\mathbf{1}}\right)$ & $\mathbf{t}_{\text {compl }}$ & Yield (\%) \\
\hline $\mathrm{Me}$ & $\mathrm{H}$ & 2.67 & 0.70 & $5.5 \mathrm{~h}$ & 95 \\
$\mathrm{Et}$ & $\mathrm{H}$ & 0.88 & 0.27 & $9.5 \mathrm{~h}$ & 90 \\
$\mathrm{i} P r$ & $\mathrm{H}$ & 2.08 & 1.33 & $4.5 \mathrm{~h}$ & 99 \\
$\mathrm{Bn}$ & $\mathrm{H}$ & 23.8 & 9.36 & $45 \mathrm{~min}$ & 80 \\
$\mathrm{Et}$ & $\mathrm{Me}$ & 0.86 & 0.16 & $17.5 \mathrm{~h}$ & 87 \\
$\mathrm{Et}$ & $\mathrm{MeC}(\mathrm{O})$ & 0.90 & 0.35 & $8.5 \mathrm{~h}$ & 86 \\
\hline
\end{tabular}

Based on the experimental data, the overall reactivity order of the different derivatives $\left(R^{2} / R^{1}\right)$ is the following:

$$
\mathrm{Bn} / \mathrm{H}>>{ }^{\mathrm{i}} \mathrm{Pr} / \mathrm{H} \sim \mathrm{Me} / \mathrm{H}>\mathrm{Et} / \mathrm{C}(\mathrm{O}) \mathrm{Me}>\mathrm{Et} / \mathrm{H}>\mathrm{Et} / \mathrm{Me} .
$$

Biologically important $\alpha$-hydroxyphosphonic acids $(\mathbf{3 8}, \mathbf{4 0})$ were prepared by the prolonged (1-2 days) heating of various hydroxyphosphonates with a large excess of hydrochloric acid (Scheme 20) [95].<smiles>CCOP(=O)(OCC)C(O)C(C)C</smiles>

37

\section{$\Delta, 1-2$ days 20 eq. $\mathrm{HCl}$}

$\mathrm{n}=10,11$<smiles>CCOP(=O)(CC(O)[AlH]C)OCC</smiles>

39<smiles>CCCC(O)C(O)(O)P(=O)(O)O</smiles>

38

$\mathrm{m}=8,10$<smiles>CC1(O)CCCC1C(O)CP(=O)(O)O</smiles>

Scheme 20. Acidic hydrolysis of biological active $\alpha$-hydroxyphosphonates (37 and 39).

$\alpha$-Hydroxyphosphonic acids (42) were prepared by the hydrochloric acid-promoted hydrolysis of hydroxyphosphonates (41) (Scheme 21) [96]. The hydrolysis was performed using $6 \mathrm{~N} \mathrm{HCl}$ in dioxane-water at $80{ }^{\circ} \mathrm{C}$ for 3 days.<smiles>[R]OP([R])(=O)C(O)c1ccc([X])cc1</smiles>

41

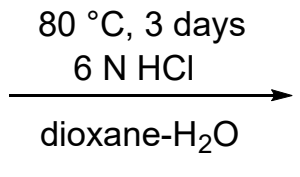

$\mathrm{R}=$ Menthyl<smiles>[X]c1ccc(C(O)P(=O)(O)O)cc1</smiles>

42

$$
\mathrm{X}=\mathrm{OMe}, \mathrm{H}
$$

Scheme 21. Preparation of biologically active $\alpha$-hydroxy-benzylphosphonic acids (42).

We investigated the acid-catalyzed reactions of a series of $\alpha$-hydroxy-benzylphosphonates (43) in order to evaluate the effect of the ester function, and the substituents in the phenyl ring 
on the rate (Scheme 22) [97]. The reactions were performed in water with 3 equivalents of hydrochloric acid, and depending on the substituents, the completion took $2.5-9.5 \mathrm{~h}$. Electronwithdrawing substituents increased the reaction rate, while electron-releasing substituents slowed down the hydrolysis. The experimental and kinetic data are summarized in Table 4, while representative concentration profiles of the hydrolyses are shown in Figure 4.

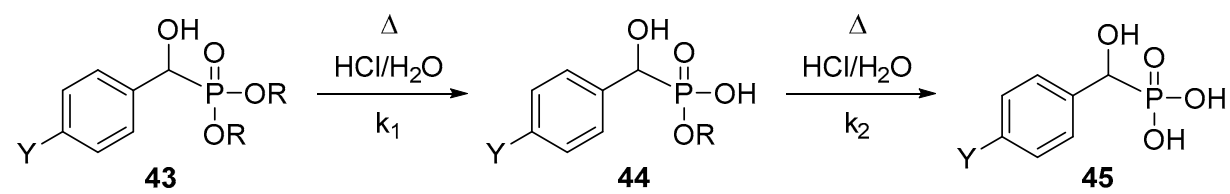

$\mathrm{R}=\mathrm{Me}, \mathrm{Et}$

$\mathrm{Y}=\mathrm{H}, \mathrm{NO}_{2}, \mathrm{Cl}, \mathrm{F}, \mathrm{CF}_{3}, \mathrm{Me}$

Scheme 22. Two-step acidic hydrolysis of substituted $\alpha$-hydroxybenzylphosphonates (43).

Table 4. Experimental and kinetic data on the hydrolysis of substituted $\alpha$-hydroxybenzylphosphonates (43).

\begin{tabular}{ccccccc}
\hline Entry & $\mathbf{Y}$ & $\mathbf{R}$ & Yield $\mathbf{( \% )}$ & $\mathbf{t}_{\mathbf{r}} \mathbf{( h )}$ & $\left.\mathbf{k}_{\mathbf{1}} \mathbf{( h} \mathbf{h}^{-\mathbf{1}}\right)$ & $\mathbf{k}_{\mathbf{2}}\left(\mathbf{h}^{-\mathbf{1}}\right)$ \\
\hline 1 & $\mathrm{H}$ & $\mathrm{Me}$ & 80 & 6.5 & 2.64 & 0.60 \\
2 & $\mathrm{NO}_{2}$ & $\mathrm{Me}$ & 82 & 2.5 & 5.18 & 1.24 \\
3 & $\mathrm{Cl}$ & $\mathrm{Me}$ & 90 & 5.5 & 3.36 & 0.79 \\
4 & $\mathrm{~F}$ & $\mathrm{Me}$ & 85 & 6.0 & 3.93 & 0.67 \\
5 & $\mathrm{CF}_{3}$ & $\mathrm{Me}$ & 80 & 5.5 & 2.03 & 0.61 \\
6 & $\mathrm{Me}$ & $\mathrm{Me}$ & 79 & 8 & 1.64 & 0.31 \\
7 & $\mathrm{H}$ & $\mathrm{Et}$ & 82 & 9.5 & 1.03 & 0.35 \\
8 & $\mathrm{NO}_{2}$ & $\mathrm{Et}$ & 92 & 5.5 & 1.40 & 0.61 \\
9 & $\mathrm{Cl}$ & $\mathrm{Et}$ & 87 & 8.0 & 1.08 & 0.42 \\
10 & $\mathrm{~F}$ & $\mathrm{Et}$ & 83 & 9.0 & 1.35 & 0.31 \\
\hline
\end{tabular}

$\mathrm{Y}=\mathrm{H}$

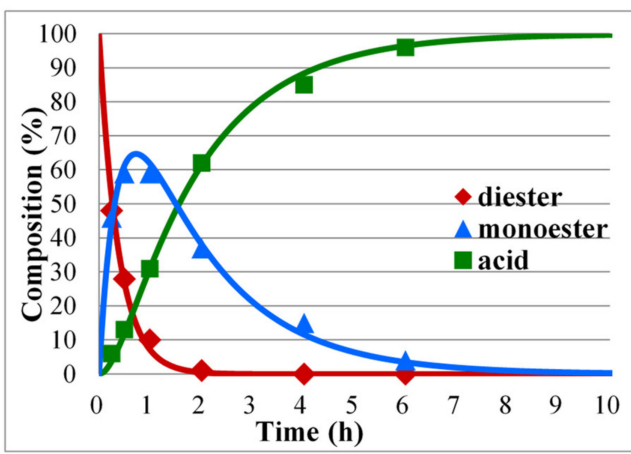

$\mathrm{Y}=\mathrm{NO}_{2}$

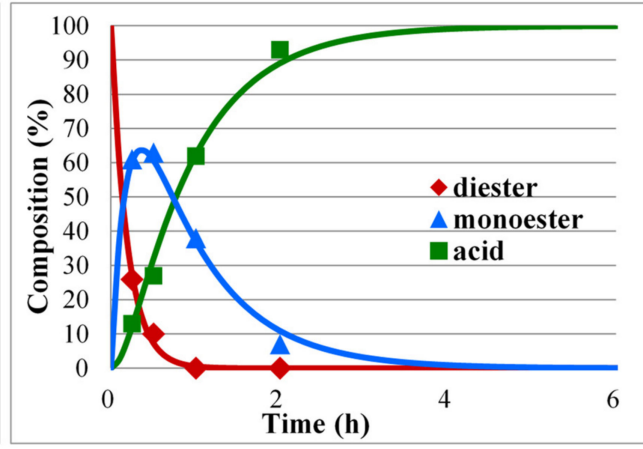

$\mathrm{Y}=\mathrm{Me}$

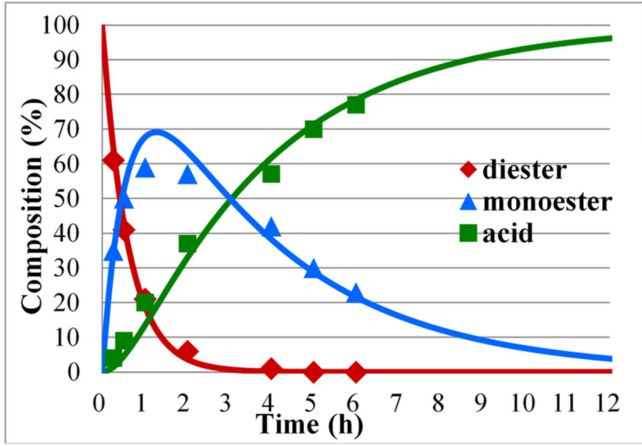

Figure 4. Concentration profiles for the components during the hydrolysis of different $\alpha$ hydroxyphosphonates (43). 
Aminophosphonic acids form another important family of bioactive compounds. These species are the analogues of amino acids. The preparation of aminomethylphosphonic acid (47) by hydrolysis involved the removal of the protecting group (Scheme 23) [3].

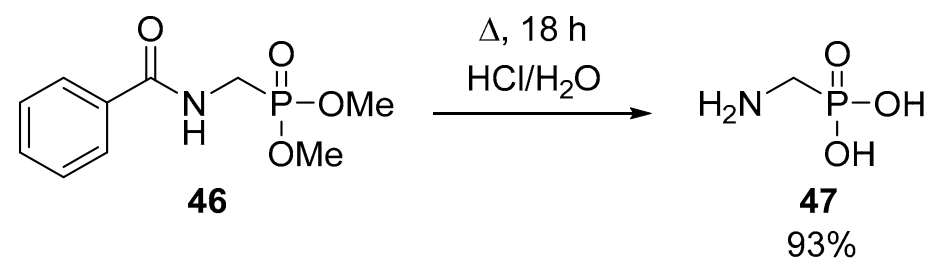

Scheme 23. Preparation of aminomethylphosphonic acid (47).

There is also an example for the $\mathrm{HBr}$ /acetic acid-catalyzed hydrolysis of aminophosphonates [98]. In the synthesis of a biologically relevant aminomethylene-bisphosphonic acid (49), the last step involved a HCl-catalyzed hydrolysis (Scheme 24) [99].<smiles>[R]NC(P(=O)(O)OCC)P(=O)(OCC)OCC</smiles>

48

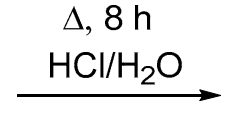<smiles>[R]NC(P(=O)(O)O)P(=O)(O)O</smiles>

49

$43-61 \%$

$\mathrm{R}=4-\mathrm{NO}_{2} \mathrm{Ph}, 2-$ pyridyl, 3-pyridyl

Scheme 24. Acidic hydrolysis of aminomethylene-bisphosphonate 48.

Phosphonic acid analogues of certain amino acids may have significant biological effects, e.g., arginine mimetics inhibit the activity of the enzymes responsible for the survival of parasites; hence, they can be used as anti-malarial agents [100]. The corresponding compounds were obtained by hydrolysis with hydrochloric acid [100], or acetic acid combined with hydrogen bromide [31]. This change in the functionality was performed in the last step of the synthesis. Similar compounds were prepared from thioureidoalkane phosphonates by treatment with acetic acid and hydrochloric acid at reflux for $7 \mathrm{~h} \mathrm{[101].}$

The hydrolysis of a benzimidazole phosphonate (50) was carried out using a $40 \% \mathrm{HBr}$ solution at reflux for $10 \mathrm{~h}$ (Scheme 25) [28].<smiles>CCOC(=O)n1c(CP(=O)(O)OC)nc2ccccc21</smiles>

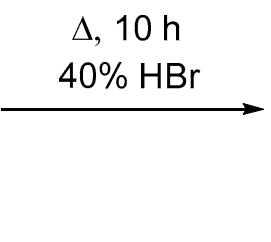<smiles>O=P(O)(O)Cc1nc2ccccc2n1CP</smiles>

Scheme 25. HBr-catalyzed hydrolysis of a benzimidazole phosphonate derivative (50).

In the following example, the hydrolysis of the succinic acid derivative (52) took place in an autocatalytic manner. The two succinate functions were also hydrolyzed under the conditions applied. The intermediates may catalyze further hydrolysis due to their acidic nature (Scheme 26) [79]. The ethanol released was removed by azeotropic distillation.

Following the spread of the MW technique, the effect of irradiation on hydrolysis was also studied [20,102]. An example from the pharmaceutical field is the synthesis of Adefovir, during which the diisopropyl ester moiety of phosphonate $\mathbf{5 4}$ was hydrolyzed in an acid-catalyzed manner under MW conditions (Scheme 27) [20]. 
<smiles>CCOC(=O)CC(C(=O)OCC)P(=O)(OCC)OCC</smiles>

52<smiles>O=C(O)CC(C(=O)O)P(=O)(O)O</smiles>

53

$80 \%$

Scheme 26. Autocatalytic hydrolysis of a succinic acid derivative (52).<smiles>CCCOP(=O)(OCC)OCCn1cnc2c(N)ncnc21</smiles>

54
MW

$130-140^{\circ} \mathrm{C}$

10-20 $\mathrm{min}$

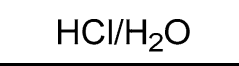<smiles>Nc1ncnc2c1ncn2CCOCP(=O)(O)O</smiles>

$92 \%$

Scheme 27. MW-assisted acidic hydrolysis of the diisopropyl ester of Adefovir (54).

The acidic hydrolysis of a series of alkyl $\alpha$-hydroxyimino- $\alpha$-( $p$-nitrophenyl) alkylphosphonates (56) revealed that the reaction rate decreases with increasing steric hindrance (Scheme 28) [103]. In addition to the ester function, the neighbouring groups also had a significant effect on the hydrolysis, e.g., when a tert-butyl group $\left(R^{2}\right)$ was replaced by a methyl substituent, a 100-fold reaction rate was observed [103].

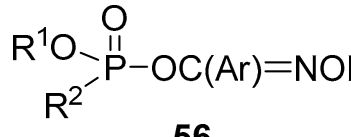
56<smiles></smiles>

57

$\mathrm{R}^{1}=\mathrm{Me}, \mathrm{Et}, \mathrm{Pr},{ }^{\mathrm{i}} \mathrm{Pr}, \mathrm{CH}_{2}{ }^{\mathrm{t}} \mathrm{Bu}, \mathrm{MeCH}{ }^{\mathrm{t}} \mathrm{Bu} \quad \mathrm{R}^{2}=\mathrm{Me}$

$\mathrm{R}^{1}=\mathrm{Et} \quad \mathrm{R}^{2}=\mathrm{Me}, \mathrm{Et},{ }^{\mathrm{t}} \mathrm{Bu}$

$\mathrm{Ar}=p-\mathrm{NO}_{2} \mathrm{Ph}$

Scheme 28. The acidic hydrolysis of alkyl $\alpha$-hydroxyimino- $\alpha$-( $p$-nitrophenyl) alkylphosphonates (56).

\section{Alkaline and Basic Hydrolysis}

\subsection{Alkaline and Basic Hydrolysis of Phosphinates}

The effect of various factors on alkaline hydrolysis was investigated in a few publications [104-106]. The influencing factors include the leaving ability of the departing group $[104,105,107,108]$, the stability of the resulting intermediate [107], the nature of the heteroatom connected to the phosphorus atom [106], the solvent [106], the pH [109] and the temperature applied, all of which may have a significant effect on the course of the hydrolysis.

Two equivalents of $\mathrm{NaOH}$ in water were used in the hydrolysis of a series of ethyl phosphinates (58) carried out with stirring at $80{ }^{\circ} \mathrm{C}$ for $6-12 \mathrm{~h}$. The sodium salt formed during the alkaline hydrolysis was converted to free acid (5) by treatment with hydrochloric acid in the second step (Scheme 29) [110]. 


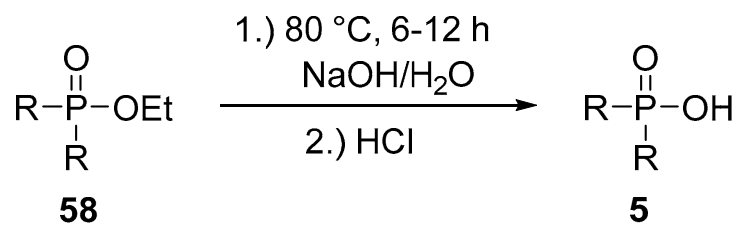

$69-83 \%$

$\mathrm{R}=4-\mathrm{F}-\mathrm{Ph}, 4-\mathrm{CF}_{3}-\mathrm{Ph}, 4-\mathrm{MeO}-\mathrm{Ph}, 4-\mathrm{Me}-\mathrm{Ph}, \mathrm{CHCH}_{2}$

Scheme 29. $\mathrm{NaOH}$-catalyzed hydrolysis of a series of ethyl phosphinates (58).

The steric effects play a significant role [111]. The alkaline hydrolysis of the ethyl diethyl, diisopropyl and di-tert-butyl phosphinates (58) was studied (Scheme 30). It was found that the increase in the steric hindrance decreased the reaction rate significantly [111]. Relative rate constants of 260, 41 and 0.08 were reported for the alkaline hydrolysis of the diethyl ester (at $70{ }^{\circ} \mathrm{C}$ ), the diisopropyl ester (at $120^{\circ} \mathrm{C}$ ) and the di-tert-butyl ester (at $120^{\circ} \mathrm{C}$ ).

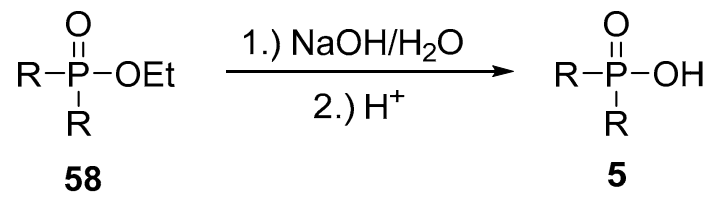

$\mathrm{R}=\mathrm{Et},{ }^{\mathrm{i}} \mathrm{Pr},{ }^{\mathrm{t}} \mathrm{Bu}$

Scheme 30. Base-catalyzed hydrolysis of a series of ethyl phosphinates (58).

In the alkaline hydrolysis of sterically hindered phosphinates (59), ethyl di-tertbutylphosphinate hydrolyzed 500 times slower than ethyl diisopropylphosphinate (Scheme 31) [112]. The major factors influencing the alkaline hydrolysis of the $P$-esters are the steric hindrance within the phosphinate and the strength of the acid resulting from the hydrolysis.

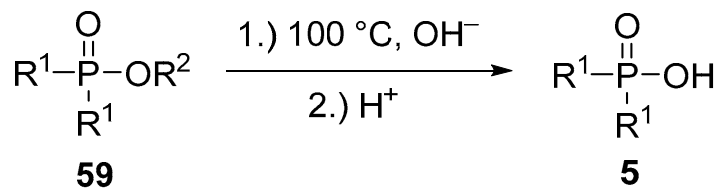

$\mathrm{R}^{1}={ }^{\mathrm{i}} \mathrm{Pr},{ }^{\mathrm{t}} \mathrm{Bu}$

$\mathrm{R}^{2}=\mathrm{Me}, \mathrm{Et}$

Scheme 31. Base-catalyzed hydrolysis of sterically hindered phosphinates (59).

During the hydrolysis of 1-alkoxyphospholene oxides, it was found that, under alkaline conditions, the 1-alkoxy-3-phospholene oxide hydrolyzed 40 times faster than the 1-alkoxy-2-phospholene oxide [104]. In another paper, a series of methyl esters (4) (Scheme 32) and other cyclic phosphinates were investigated in order to clarify the effect of alkyl groups and rings [113]. In this case, the reaction conditions and the yields were not provided.

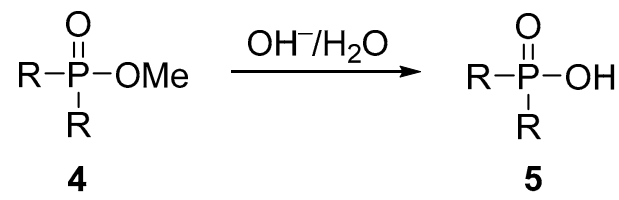

$\mathrm{R}=\mathrm{Me}, \mathrm{Et},{ }^{\mathrm{n}} \mathrm{Bu}, \mathrm{Ph}, \mathrm{Bn}$

Scheme 32. Base-catalyzed hydrolysis of a series of acyclic methyl phosphinates (4). 
The order of reactivity for the open chain derivatives was the following [113]:

$$
\mathrm{Me}>\mathrm{Ph}>\mathrm{Bn}>\mathrm{Et}>{ }^{\mathrm{n}} \mathrm{Bu}
$$

In the case of cyclic derivatives, the following order of reactivity was found [113]:

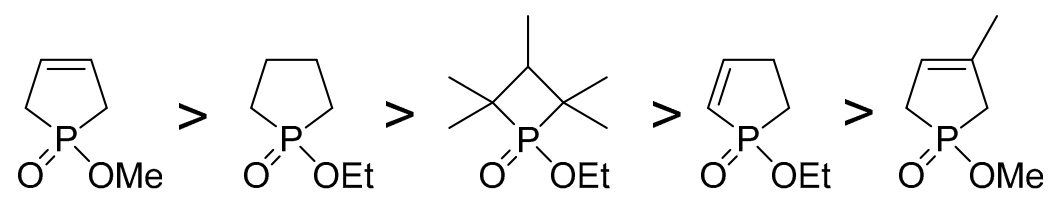

The alkaline hydrolysis of other cyclic and open-chain phosphinates was also studied [114] and the rate constants were determined. In the case of less-soluble phosphinates, alcohol-water mixtures were used. The hydrolysis of five-membered cyclic phosphinates was faster than that of the open-chain and six-membered cyclic phosphinates (Table 5).

Table 5. The alkaline hydrolysis of various cyclic and open-chain phosphinates.

\begin{tabular}{|c|c|c|c|c|}
\hline \multirow{2}{*}{ Starting Phosphinate } & \multirow{2}{*}{ Solvent } & \multicolumn{3}{|c|}{ Rate Constant, $1 \mathrm{~mole}^{-1} \mathrm{~s}^{-1} \times 10^{4}$} \\
\hline & & $50^{\circ} \mathrm{C}$ & $60^{\circ} \mathrm{C}$ & $70^{\circ} \mathrm{C}$ \\
\hline & $50 \%$ alcohol-water & 1.18 & 2.24 & 4.22 \\
\hline & $80 \%$ alcohol-water & 0.300 & 0.568 & 1.08 \\
\hline & $50 \%$ alcohol-water & 0.730 & 1.39 & 2.63 \\
\hline
\end{tabular}

The effect of various heteroaromatic substituents was also studied in the hydrolyses carried out in 50\% aqueous dioxane: the hydrolysis of di(2-furyl)-, di(2-thienyl)- and diphenylphosphinic acid ethyl esters performed using one equivalent of sodium hydroxide for 72-120 h was compared (Figure 5) [115]. It was found that the hydrolysis of the furyl derivative was the fastest, while that of the phenyl species was the slowest.<smiles>CCOP(=O)(OCC)c1ccccc1</smiles>

Figure 5. The effect of various heteroaromatic substituents in alkaline hydrolysis.

Bergesen investigated the difference between the alkaline hydrolysis of the cis and trans isomers of a four-membered cyclic phosphinate (60) in 50\% ethanol-water (Scheme 33) [39]. The results showed that the cis isomer hydrolyzed ca. seven times faster. This may be explained by the fact that, in the case of the trans isomer, the three methyl groups block the access of the hydroxy ion, as compared to the case when only two methyl groups are in the neighborhood, as in the cis isomer.<smiles>CCOP1(=O)C(C)(C)C(C)C1(C)C</smiles>

60

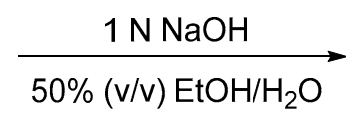

cis/trans

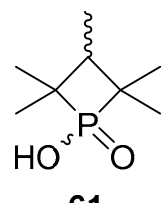

61

Scheme 33. Alkaline hydrolysis of the isomers of a four-membered cyclic phosphinate (60). 
The alkaline hydrolysis of different alkyl diethylphosphinates (59) was also investigated (Scheme 34) [38]. The reactivity of the alkoxy groups was influenced by the steric bulk of the alkyl group. The value of the rate constants decreased with the increase of the steric hindrance. However, the exact conditions and outcomes were not reported.

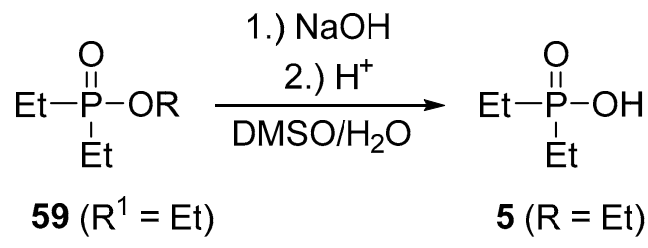

$\mathrm{R}=\mathrm{Me}, \mathrm{Et},{ }^{\mathrm{n}} \mathrm{Pr},{ }^{\mathrm{i}} \mathrm{Pr},{ }^{\mathrm{n}} \mathrm{Bu},{ }^{\mathrm{i}} \mathrm{Bu},{ }^{\mathrm{s}} \mathrm{Bu}, \mathrm{Hex}$, Oct, Dodecyl

Scheme 34. Alkaline hydrolysis of diethyl phosphinates (59) in a DMSO-water system.

It was confirmed by another group that the base-catalyzed hydrolysis became less efficient with the increasing steric requirement of the alkyl group of the alkoxy moiety [104].

Furthermore, 1-Hydroxy-3,4-diphenylphosphole-1-oxide (63) was prepared from the corresponding phenoxyphosphole oxide (62) by alkaline hydrolysis (Scheme 35) [105]. Then, the corresponding phosphinic acid (61) was liberated with $\mathrm{HCl}$.<smiles>O=P1(Oc2ccccc2)C=C(c2ccccc2)C(c2ccccc2)=C1</smiles>

62

\section{1.) $\mathrm{NaOH} / \mathrm{H}_{2} \mathrm{O}$ \\ 2.) $\mathrm{H}^{+} /$acetone}<smiles>O=P1(O)C=C(c2ccccc2)C(c2ccccc2)=C1</smiles>

63

Scheme 35. NaOH-catalyzed hydrolysis of 1-phenoxy-3,4-diphenylphosphol oxide (62).

Studying the hydrolysis of different esters, Clarke and co-workers concluded that the smaller the electron-releasing effect of the substituents was, the greater the rate constant became (Figure 6) [105].<smiles>CCOP1(=O)C=C(C)C(OP2(=O)C=C(C)C(C)=C2)=C1</smiles>

Figure 6. The reactivity order of different cyclic phosphinates in alkaline hydrolysis.

The $\mathrm{NaOH}$-catalyzed hydrolysis of substituted aryl diphenylphosphinates (64) was also investigated (Scheme 36) [106]. It was found that the value of the rate constant decreased with the decrease of the electron-withdrawing ability of the substituent $Y$ in the departing aryl ring. All of the reactions were carried out under pseudo-first-order kinetic conditions, but the exact circumstances were not reported.

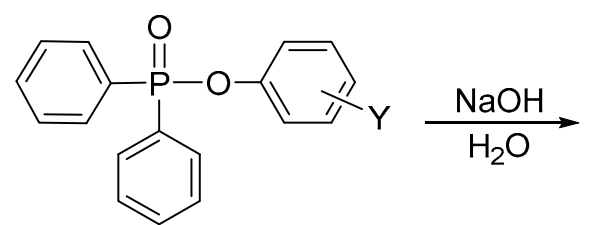

64<smiles>O=P(O)(c1ccccc1)c1ccccc1</smiles>

9

$\mathrm{Y}=\mathrm{H}, 3,4-\mathrm{diNO}_{2}, 4-\mathrm{NO}_{2}$, 3-Cl, 4-Cl, 4-CN, 4-CHO, 3-COMe, 4-COMe

Scheme 36. $\mathrm{NaOH}$-calatyzed hydrolysis of various aryl diphenylphosphinates (64). 
Hydrolyses of various aryl diphenylphosphinates (64) carried out using $\mathrm{OH}^{-}$and imidazole catalysis were compared (Scheme 37) [116]. In addition to the substituent dependence, it was found that the imidazole-promoted hydrolyses were significantly faster than the $\mathrm{OH}^{-}$-catalyzed examples. This paper was merely a kinetic study, and the exact conditions were not reported.

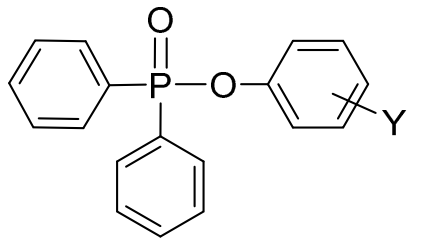

64

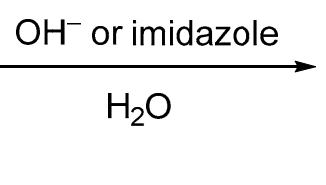

$\mathrm{Y}=\mathrm{H}, 3-\mathrm{NO}_{2}, 4-\mathrm{Cl}, 4-\mathrm{NO}_{2}, 4-\mathrm{COMe}, 4-\mathrm{Me}, 4-\mathrm{MeO}$

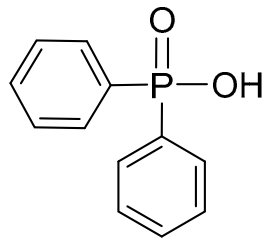

9

Scheme 37. $\mathrm{OH}^{-}$ion- and imidazole-calatyzed hydrolysis of various aryl diphenylphosphinates (64).

The effect of alkyl groups was also studied in the case of diphenylphosphinothioates. It was found that the electron-withdrawing effect accelerates the process, whilst the electronreleasing effect greatly slows it down [117].

It was also found that thioesters $(>\mathrm{P}(\mathrm{O}) \mathrm{SR})$ are much more reactive than the oxo analogues. The reason is that the RS substituent is a better leaving group. In addition, the $\mathrm{R}$ group has a greater influence on the hydrolyzing ability of OR than it does on that of SR $[106,118]$. Comparing the reactivity of the $\mathrm{P}=\mathrm{O}$ and $\mathrm{P}=\mathrm{S}$ derivatives, it can be said that in the case of alkaline hydrolysis, the oxo derivatives are more reactive. [106,109].

The effect of solvents and solvent mixtures was also studied. It was found that the hydrolysis was slightly faster in solvent mixtures [106]. Possible solvent mixtures may be $60 \%$ dimethoxyethane in water [104,114], 60\% dimethyl ether in water [106], 20\% acetonitrile in water [119], and 60\% acetone in water [117], but there are other options as well, e.g., hydrolysis in dioxane-water [117] or in methanol-water [117].

\subsection{Alkaline and Basic Hydrolysis of Phosphonates}

The alkaline hydrolysis of a series of diethyl alkylphosphonates (65) was investigated in DMSO $/ \mathrm{H}_{2} \mathrm{O}$. Based on the results, an order of reactivity was established on the basis of the nature of the various alkyl chains (Scheme 38) [38]. Higher reactivity was observed for the esters with an $n$-alkyl substituent, while the rate of the hydrolysis decreased with increasing steric hindrance.

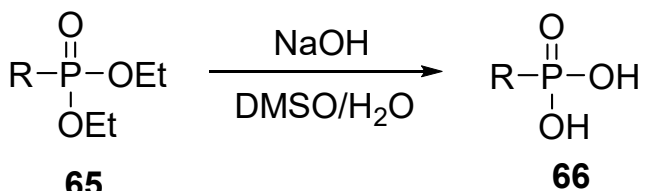

$$
\mathrm{R}=\mathrm{Me}, \mathrm{Et},{ }^{\mathrm{n}} \mathrm{Pr},{ }^{\mathrm{i}} \mathrm{Pr},{ }^{\mathrm{n}} \mathrm{Bu},{ }^{\mathrm{B}} \mathrm{Bu},{ }^{\mathrm{s}} \mathrm{Bu}, \text { Hex, Oct, Dodecyl }
$$

Scheme 38. Alkaline hydrolysis of diethyl alkylphosphonates (65) in aqueous DMSO solution.

The steric effects had a greater influence on the hydrolysis of phosphonates compared to that of carboxylic esters. In addition, it was found that the hydrolysis of six- and seven-membered cyclic phosphonates is faster than that of the open-chain analogues [38].

It was observed that the rate of the hydrolysis was greatly influenced by the nature of the leaving group and the substituents on the phosphorus atom. Aksnes et al. studied the alkaline hydrolysis of various diethyl alkyl-, chloromethyl- and dichloromethylphosphonates (65) in an acetone-water solvent-mixture (Scheme 39) [120]. The presence of the chloromethyl or dichloromethyl substituents increased the reaction rate. Compared 
to the hydrolysis of carboxylic esters, the hydrolysis of phosphonates is less sensitive to electronic effects.

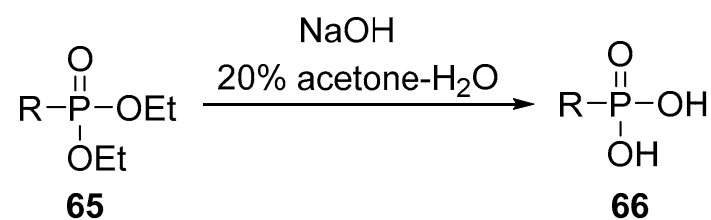

$\mathrm{R}=\mathrm{Me}, \mathrm{Et}, \mathrm{ClCH}_{2}, \mathrm{Cl}_{2} \mathrm{CH}$

Scheme 39. Hydrolysis of diethyl phosphonates (65) in aqueous acetone.

As an interesting example, a diphenyl adenosilvinylphosphonate (67) was hydrolyzed in the presence of ammonium fluoride (Scheme 40) [121].<smiles>N#CC1C(/C=C/P(=O)(O)Oc2ccccc2)OC(n2cnc3c(N)ncnc32)C1O</smiles>

67

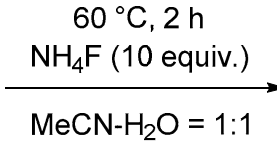

$\mathrm{MeCN}-\mathrm{H}_{2} \mathrm{O}=1: 1$<smiles>Nc1ncnc2c1ncn2C1OC(C=CP(=O)(O)O)C(O)C1O</smiles>

68

Scheme 40. $\mathrm{NH}_{4} \mathrm{~F}$-catalyzed hydrolysis of an adenosilvinylphosphonate derivative (67).

Other vinylphosphonic esters (69) were hydrolyzed under similar conditions (Scheme 41) [121].<smiles>[R]C=CP(=O)(Oc1ccccc1)c1ccccc1</smiles>

69 $60^{\circ} \mathrm{C}, 2 \mathrm{~h}$<smiles>CN(C)C[Na]</smiles>

$\mathrm{MeCN}-\mathrm{H}_{2} \mathrm{O}=1: 1$<smiles>[R]C=CP(=O)(O)O</smiles>

70

$80-95 \%$

$\mathrm{R}=\mathrm{Ph}, p$-chlorophenyl, $p$-nitrophenyl, $p$-tosil, $\mathrm{Bn},{ }^{\mathrm{n}} \mathrm{Bu},{ }^{\mathrm{i}} \mathrm{Bu}$

Scheme 41. $\mathrm{NH}_{4}$ F-catalyzed hydrolysis of a series of diphenyl vinylphosphonates (69).

It was noted that, in the case of benzyl esters, the corresponding acids may also be obtained by catalytic hydrogenation.

The enzyme-catalyzed hydrolysis of diphenyl alkylphosphonates (71) was also reported [121,122]. As a matter of fact, the hydrolysis of the first ester function was performed by applying base catalysis, while a phosphodiesterase enzyme was used in the second step (Scheme 42).

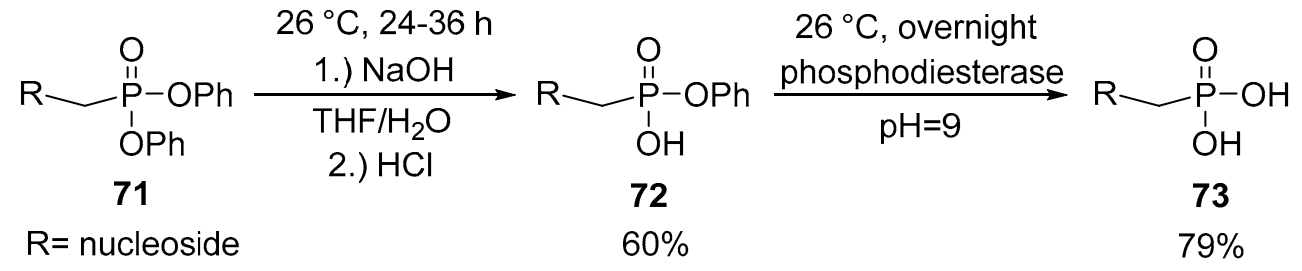

Scheme 42. Semi-enzymatic hydrolysis of diphenyl alkylphosphonates (71).

The above phenomenon was investigated by several groups. Hudson et al. also studied the effect of the $P$-substituents on the reactivity [92]. 
In the acidic hydrolysis of dialkyl methylphosphonates, the order of reactivity was the following [92]:

$$
{ }^{\mathrm{i}} \mathrm{Pr}>\mathrm{Me}>\mathrm{Et} \sim \text { neopentyl }
$$

In contrast, applying base-catalyzed hydrolysis, the order of reactivity was the following [92]:

$$
\mathrm{Me}>\mathrm{Et}>{ }^{\mathrm{i}} \mathrm{Pr}>\text { neopentyl }
$$

In the case of diaryl esters, the rate constants were significantly higher. The rate is dependent on the electronic effects: electron-donating substituents slow down the hydrolysis [92]. This was also observed for cyclic phosphonates [123]. Ring cleavage also takes place during their alkaline hydrolysis [109].

The alkaline hydrolysis of phenyl methylphosphonate and p-nitrophenyl methylphosphonate (74) with the application of $\mathrm{NaOH}$ was also studied (Scheme 43) [124]. In this case, the nucleophilic attack of the hydroxide ion occurs on the phosphorus atom of the $\mathrm{P}=\mathrm{O}$ function. The rate of the reaction increased with the increase of the hydroxide ion concentration.

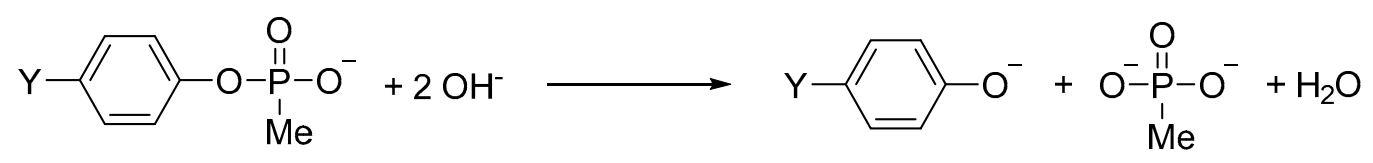

74

$\mathrm{Y}=\mathrm{H}, \mathrm{NO}_{2}$

Scheme 43. Alkaline hydrolysis of aryl methylphosphonates 66 using $\mathrm{NaOH}$.

Dimethyl 4-toluenesulfonyloxymethylphosphonate (75) was treated with 60\% pyridine$\mathrm{H}_{2} \mathrm{O}$ at room temperature to give the monomethyl derivative at an $82 \%$ yield (Scheme 44) [125]. The product was a good phosphorylating reagent to protect nucleosides.<smiles>COP(=O)(CO[As])OC</smiles>

75
1.) $26{ }^{\circ} \mathrm{C}$, overnight

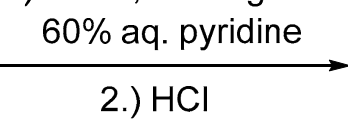

2.) $\mathrm{HCl}$<smiles>COP(=O)(O)CO[Na]</smiles>

76

$82 \%$

Scheme 44. Preparation of methyl 4-toluenesulfonyloxymethylphosphonate (75) using aqueous pyridine.

The kinetics of the selective monohydrolysis of ethyl $p$-nitrophenyl chloromethylphosphonate (77) were studied in micellar solutions of a cationic surfactant (Scheme 45) $[126,127]$.

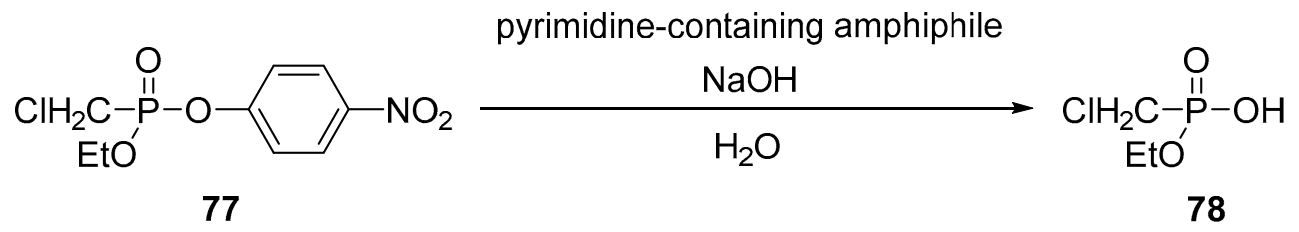

Scheme 45. Alkaline hydrolysis of ethyl p-nitrophenyl chloromethylphosphonate (77) in micellar solutions.

In summary, the temperature, the solvent and the $\mathrm{pH}$ applied have a significant impact on the course of the alkaline hydrolysis. Considering the effect of the $\mathrm{C}$-substituents attached to the $\mathrm{P}$ atom, the reactivity of the phosphonates decreases with increasing steric congestion, and increases due to the effect of electron-withdrawing substituents (e.g., in diethyl chloromethylphosphonate compared to diethyl methylphosphonate). Regarding 
the effect of the OR function, electron-withdrawing $\mathrm{R}$ groups (e.g., $\mathrm{NO}_{2} \mathrm{Ph}$ ) increase the rate of the reaction. It is also noteworthy that the hydrolysis of aryl esters is faster than that of their aliphatic counterparts.

\section{Dealkylation}

\subsection{Dealkylation of Phosphinates}

In the case of certain ester groups, a high temperature treatment may also be effective to cleave the $\mathrm{O}-\mathrm{C}$ bond. This is exemplified by the pyrolysis of diphenylphosphinates (30) with branched alkyl groups, affording the corresponding acid quantitatively (Scheme 46) [46]. This transformation required a treatment at $120-335{ }^{\circ} \mathrm{C}$ for $15 \mathrm{~min}$, leaving diphenylphosphinic acid (9) in a solid form. The olefin that was liberated departed as a gas.

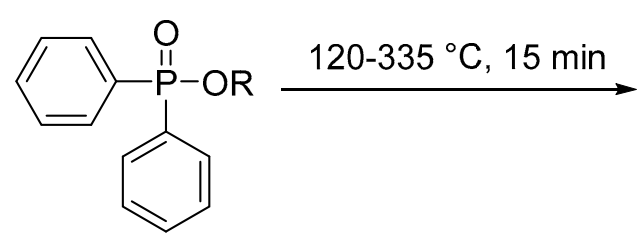

30<smiles>O=P(O)(c1ccccc1)c1ccccc1</smiles>

9

$$
\mathrm{R}={ }^{\mathrm{t}} \mathrm{Bu},{ }^{\mathrm{i}} \mathrm{Bu},{ }^{\mathrm{i}} \mathrm{Pr}
$$

Scheme 46. Pyrolysis of various alkyl diphenylphosphinates (30).

Dealkylations are most often performed using chemical agents, such as trimethylsilyl halides (TMSX). Following the fission, there is need for a treatment with water or methanol to form the corresponding acid [28]. A methyl-heptylphosphinic acid analogue of valproic acid (80) was prepared, in the hope of its bioactivity. In the final step of the synthesis, the resulting ethyl ester was cleaved by trimethylsilyl bromide (TMSBr) to give the target acid (80) (Scheme 47) [128]. The exact conditions were not reported.<smiles>CCCC(CCC)P(C)(=O)OCC</smiles>

79<smiles>O=[W]Br</smiles>

2.) $\mathrm{H}_{2} \mathrm{O}$<smiles>CCCC(CC)P(C)(=O)O</smiles>

80

\section{$80 \%$}

Scheme 47. Dealkylation of methyl-heptylphosphinate (79) using TMSBr.

Another example is the conversion of ethyl divinylphosphinate (81) to the corresponding acid (83) by treatment with TMSBr followed by methanolysis (Scheme 48) [129].

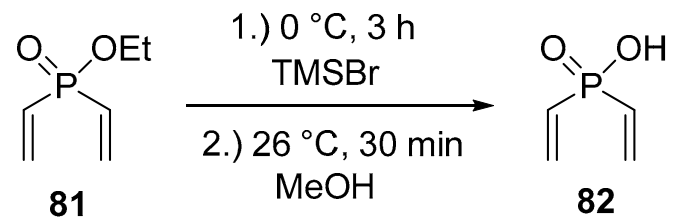

Scheme 48. Preparation of divinylphosphinic acid (82) by ethyl fission with TMSBr.

In addition to trimethylsilyl bromide, the iodide derivative (TMSI) is also a suitable dealkylating agent. Its application was demonstrated via the deethylation of a cyclic ethyl phosphinate (83) (Scheme 49) [130]. 
<smiles>CCOP1(=O)C(Br)CCC1(Br)CC</smiles>

83

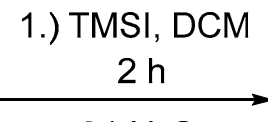

2.) $\mathrm{H}_{2} \mathrm{O}$

$\longrightarrow$<smiles>O=P1(O)C(Br)CCC1Br</smiles>

84

$90 \%$

$\mathrm{Ar}=p-\mathrm{NO}_{2} \mathrm{Ph}$

Scheme 49. Dealkylation of an 1-ethoxyphospholane oxide (83) using TMSI.

\subsection{Dealkylation of Phosphonates}

Certain phosphonates may also decompose on heating to give the corresponding acids. The di-tert-butyl esters (e.g., 85), which may undergo dealkylation at $80^{\circ} \mathrm{C}$, are particularly suitable. The exact conditions were not reported in the example shown in Scheme 50 [79].

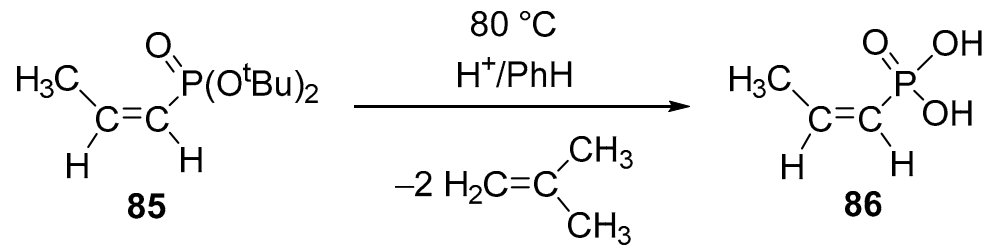

Scheme 50. Thermal dealkylation of a di-tert-butyl vinylphosphonate (85).

The dealkylation of the esters (65) may also take place with the aid of various reagents, most commonly with TMSX [131-136]. In the first step, the corresponding bis-trimethylsilyl ester (87) is formed, which provides the corresponding phosphonic acid (66) on treatment with water or methanol. This protocol, illustrated in Scheme 51, may be considered to be a gentle and convenient method $[79,137]$.

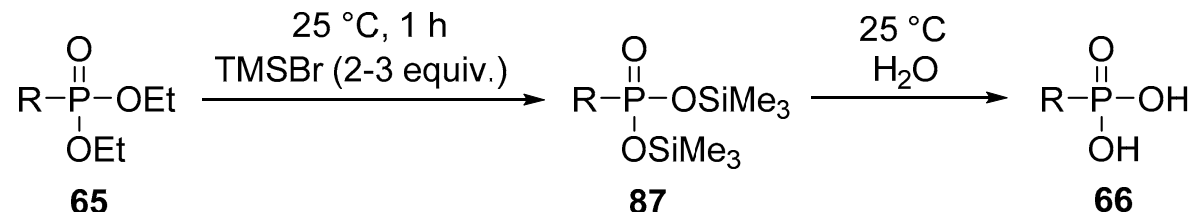

\section{$\mathrm{R}=\mathrm{COOEt}, \mathrm{CH}_{2} \mathrm{COOEt}, \mathrm{CH}_{2} \mathrm{CH}_{2} \mathrm{COOEt}, \mathrm{C}(\mathrm{O}) \mathrm{Me}$}

Scheme 51. Dealkylation of diethyl alkylphosphonates (65) using TMSBr.

Later on, the mechanism of the reaction was investigated, and it was found that TMSBr attacks the oxygen atom of the $\mathrm{P}=\mathrm{O}$ function [138]. The sequence of the double dealkylation with TMSI is shown in Scheme $52[139,140]$.<smiles>COP(=O)(Cc1ccccc1)OC</smiles><smiles>COP(=O)(OC)OC</smiles><smiles>CC(C)(C)C</smiles><smiles>COP(=O)(Cc1ccccc1)OC</smiles><smiles>O=P(O)(O)CBr</smiles><smiles>O=COS(=O)(=O)O</smiles><smiles>COP(=O)(Cc1ccccc1)OC</smiles>
-Mel<smiles>COP(=O)(OC)OC</smiles>

Scheme 52. Proposed mechanism for the double dealkylations with TMSI. 
The cleavage with trimethylsilyl chloride (TMSCl) is not an often-used procedure [59]. This derivative is less reactive than TMSBr, and therefore requires a longer reaction time at a higher temperature. However, its lower cost and easier handling justifies its application. In a typical example, the mixture was heated up to $130-140{ }^{\circ} \mathrm{C}$ using three to four equivalents of TMSCl in chlorobenzene. The complete removal of the ester function took 8-36 h. The corresponding phosphonic acids (66) were obtained after hydrolysis (Scheme 53) [140].

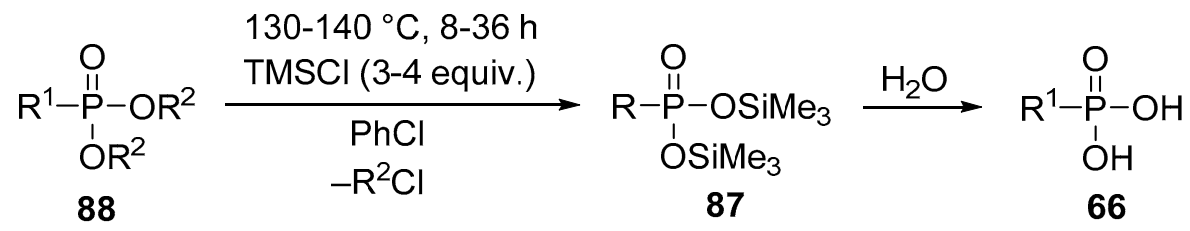

$$
\begin{aligned}
& \mathrm{R}^{1}=\mathrm{CH}_{2} \mathrm{COOMe}, \mathrm{CH}_{2} \mathrm{COOEt}, \mathrm{CH}_{2} \mathrm{Ph}, \mathrm{CH}_{2} \mathrm{COPh} \\
& \mathrm{R}^{2}=\mathrm{Me}, \mathrm{Et}
\end{aligned}
$$

Scheme 53. Double cleavage with TMSCl.

The TMSC1 reagent can also be used in the preparation of PMEA/PMPA (90), which are known as antiviral agents (Scheme 54) [141].<smiles>[R]C(Cn1cnc2c(N)ncnc21)OCP(=O)(OCC)OCC</smiles>

89

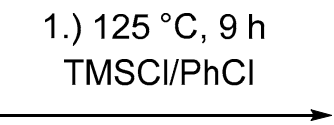

2.) $\mathrm{H}_{2} \mathrm{O}$<smiles>[R][C@@H](Cn1cnc2c(N)ncnc21)OCP(=O)(O)O</smiles>

90

$\mathrm{R}=\mathrm{H}, \mathrm{PMEA} \quad 96 \%$

$\mathrm{R}=\mathrm{Me}, \mathrm{PMPA} \quad 75 \%$

Scheme 54. Preparation of two antiviral agents (90).

McKenna compared the reactivity of TMSCl and TMSBr, and found that while the dealkylation with $\mathrm{TMSCl}$, in most cases, was not complete within 1-9 days, the reaction with the bromide derivative was complete within 1-3 h (Table 6) [57].

\begin{tabular}{|c|c|c|c|c|c|c|c|c|c|}
\hline \multicolumn{2}{|c|}{$\begin{array}{c}\text { Dialkyl Phosphonate } \\
\operatorname{RP}(\mathrm{O})\left(\mathrm{OR}^{\prime}\right)_{2}\end{array}$} & \multicolumn{4}{|c|}{ TMSCl } & \multicolumn{4}{|c|}{ TMSBr } \\
\hline $\mathbf{R}$ & $\mathbf{R}^{\prime}$ & Equiv. & $\begin{array}{l}\text { Temp. } \\
\left({ }^{\circ} \mathrm{C}\right)\end{array}$ & $\begin{array}{l}\text { Time } \\
\text { (days) }\end{array}$ & $\begin{array}{l}\text { Yields } \\
(\%)\end{array}$ & Equiv. & $\begin{array}{l}\text { Temp. } \\
\left({ }^{\circ} \mathrm{C}\right)\end{array}$ & $\begin{array}{l}\text { Time } \\
\text { (h) }\end{array}$ & $\begin{array}{c}\text { Yields } \\
(\%)\end{array}$ \\
\hline $\mathrm{CH}_{2}=\mathrm{CH}$ & Et & 2.7 & $69-72$ & 5 & 94 & 1.5 & 25 & 1.2 & $>99$ \\
\hline $\mathrm{PhCH}_{2}$ & Et & 2.2 & 40 & 1 & $<5$ & 1.7 & 25 & 2.0 & $>99$ \\
\hline $\mathrm{EtOCH}_{2} \mathrm{CH}_{2}$ & Et & 2.9 & 40 & 1 & $<10$ & 1.7 & 25 & 0.7 & $>99$ \\
\hline $\mathrm{Cl}_{3} \mathrm{C}$ & Et & 5.4 & $>72$ & 8 & 13 & 1.5 & $61-69$ & 2.7 & $>99$ \\
\hline $\mathrm{PhC}(\mathrm{O})$ & $\mathrm{Me}$ & 1.9 & 25 & 9 & 12 & 1.5 & 25 & 1.7 & $>99$ \\
\hline
\end{tabular}

Table 6. Comparison of the reactivity of TMSCl and TMSBr.

The dealkylation reactions could be promoted by the addition of sodium iodide as a co-reagent to TMSCl [142]. In a few cases, the corresponding phosphonic acids (66) were obtained in good yields after treatment with this mixture of reagents at room temperature for 15-60 min (Scheme 55) [143]. 


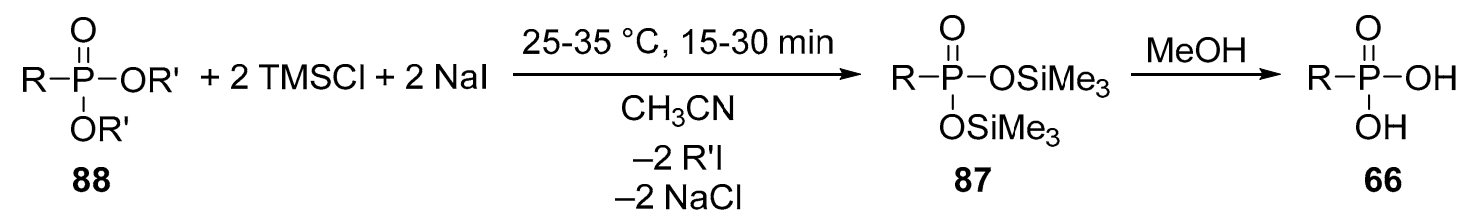

$\mathrm{R}=\mathrm{Bn}, \mathrm{CCl}_{3}, \mathrm{C}(\mathrm{O}) \mathrm{Me}$

$\mathrm{R}^{\prime}=\mathrm{Me}, \mathrm{Et}, \mathrm{i}-\mathrm{Pr}$

Scheme 55. Double dealkylation using TMSCl in the presence of sodium iodide.

Using lithium iodide, dialkyl phosphonates were cleaved under milder conditions [144]. In most of the cases, TMSBr was used in the dealkylations [145-171].

The conversion of phosphonates to the corresponding acids plays an important role in the synthesis of drugs. This is illustrated by the last step of the synthesis of Tenofovir (90) (Scheme 56) [172]. TMSCl/NaBr was applied in the preparation of other anti-HIV agents as well [173].

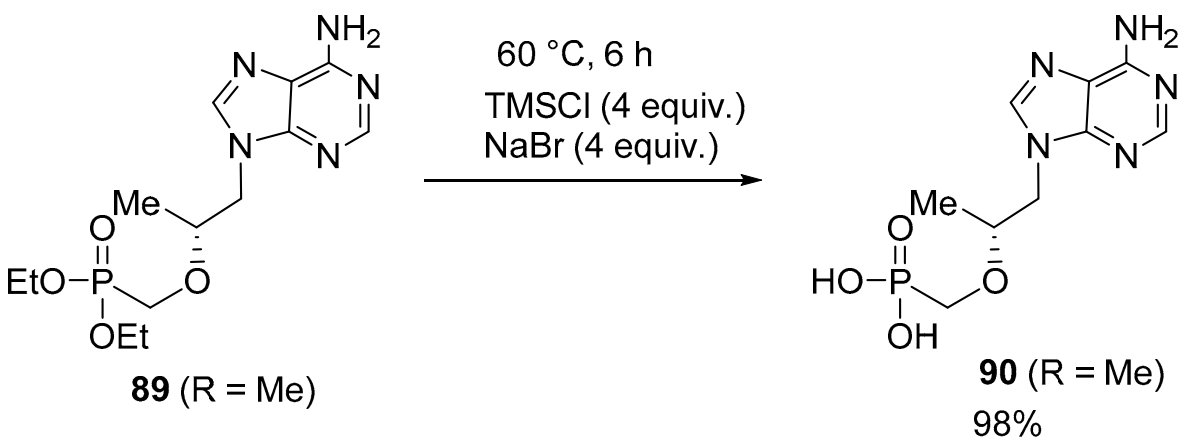

Scheme 56. Preparation of an anti-HIV agent (90) by dealkylation with TMSCl/NaBr.

The double cleavage of the $\mathrm{P}(\mathrm{O})\left(\mathrm{O}^{\mathrm{i}} \mathrm{Pr}\right)_{2}$ function in a series of diisopropyl esters (88) was performed with TMSBr at $60{ }^{\circ} \mathrm{C}$ for 4-24 h. Using three equivalents of TMSBr, yields of around $80 \%$ were reported. A work-up including a treatment with $\mathrm{NaOH}$ and methanol gave the mono-Na salt of the phosphonic acid (91) (Scheme 57) [174].

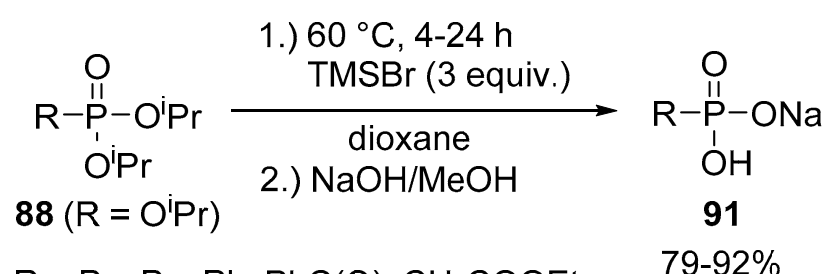

$\mathrm{R}=\mathrm{Bu}, \mathrm{Bn}, \mathrm{Ph}, \mathrm{PhC}(\mathrm{O}), \mathrm{CH}_{2} \mathrm{COOEt}$

$79-92 \%$

Scheme 57. Dealkylation of a series of diisopropyl esters (88) with TMSBr.

Certain analogues of purine-based phosphonic acids are able to inhibit the FBSase enzyme, making them effective in the treatment of type 2 diabetes. During the synthesis of these type of compounds, the cleavage of the ester group was performed with TMSBr (Scheme 58) [175].

TMSBr may also be used in the dealkylation of metal complexes (95) (Scheme 59) [176].

In addition to TMSBr, boron tribromide was also proven to be an effective dealkylating reagent [177]. In this case, the reaction resulted in the formation of borophosphonate oligomers $[-\mathrm{O}-\mathrm{PR}(\mathrm{O}-)-\mathrm{O}-\mathrm{B}(\mathrm{O}-)(\mathrm{O}-)]_{\mathrm{n}}$, along with the alkyl bromide by-product [53]. The methanolysis of the intermediate led to free phosphonic acid (66) and $\mathrm{B}(\mathrm{OMe})_{3}$ (Scheme 60$)$. 
<smiles>CCOP(=O)(OCC)c1ccc(-c2nc3c(N)ncnc3n2CC(C)(C)C)o1</smiles>

92
1.) $25^{\circ} \mathrm{C}, 12 \mathrm{~h}$ $\operatorname{TMSBr}$ (10 equiv.)

$\mathrm{MeCN}$

2.) $\mathrm{H}_{2} \mathrm{O}$<smiles>Cc1cc(P(=O)(O)O)oc1-c1nc2c(N)ncnc2n1CC(C)(C)C</smiles>

93

Scheme 58. Preparation of a purine-based phosphonic acid (93) using TMSBr.<smiles>CCOP(=O)(OCC)c1cc(CN(C)C)c(CN(C)Br)c(CN(C)Br)c1</smiles>

94

$\mathrm{M}=\mathrm{Pd}, \mathrm{Pt}$
1.) $26^{\circ} \mathrm{C}, 4 \mathrm{~h}$

$\operatorname{TMSBr}(10$ equiv.)

DCM

2.) $\mathrm{MeOH}$<smiles>CN(C)Cc1cc(P(=O)(O)O)cc(CN(C)C)c1N(C)Br</smiles>

95

Scheme 59. Modification of a complex (94) by double dealkylation.<smiles>[R]OP([R])(=O)O[R7]</smiles>

1.) $\mathrm{BBr}_{3}, \mathrm{PhMe} /$ hexane, $-30^{\circ} \mathrm{C}-70^{\circ} \mathrm{C}$

2.) $\mathrm{MeOH}, 20^{\circ} \mathrm{C}$

88

$\mathrm{R}=$ alkyl, aryl, allyl

$\mathrm{R}^{\prime}=\mathrm{alkyl}$

$89-94 \%$

Scheme 60. Cleavage of the alkoxy groups of phosphonates by $\mathrm{BBr}_{3}$.

In special cases, a cation exchange resin was used as a catalyst in dealkylations (Scheme 61) [178]. The phenylphosphonates (88) were reacted at $40{ }^{\circ} \mathrm{C}$ for a prolonged reaction time to afford phenylphosphonic acid (66) in variable yields, depending on the nature of the R group.

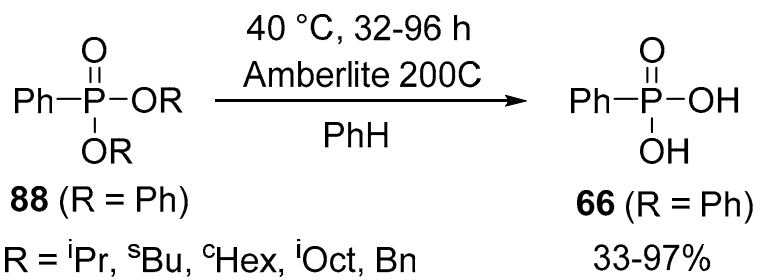

Scheme 61 . The use of cation exchange resin in dealkylations.

The dealkylation of diethyl ethylphosphonate (65) was performed using $\gamma$-alumina and silica gel. At a temperature of $300^{\circ} \mathrm{C}$, the cleavage of the P-C bond also occurred in addition to the desired fission of the $\mathrm{C}-\mathrm{O}$ bond (Scheme 62) [179].

The monodealkylation of phosphonates (98) was also elaborated using sodium iodide in polar solvents (Scheme 63) [150,180-182].

The monodealkylation of phosphonates (100) was also performed under phase transfer catalytic conditions (Scheme 64) [183]. In this case, triethylbenzylammonium bromide or triethylbenzylammonium chloride (TEBAB or TEBAC, respectively) was applied as the catalyst in the dealkylation performed at reflux for 24-150 h. 


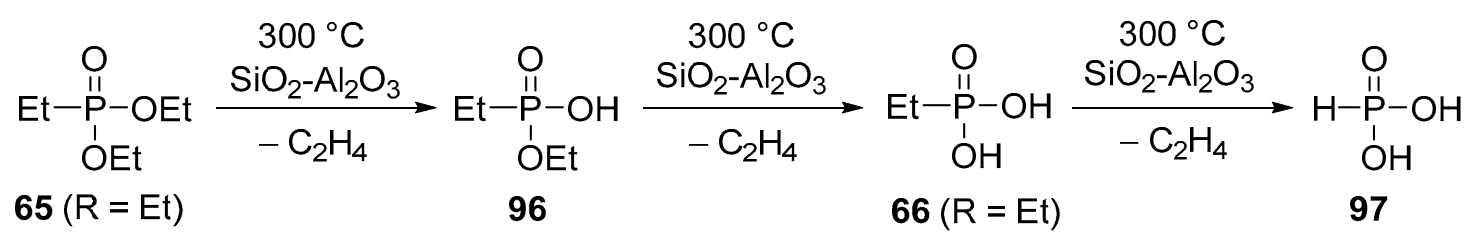

Scheme 62. Catalytic dealkylation of diethyl ethylphosphonate (65) using $\gamma$-alumina and silica gel.

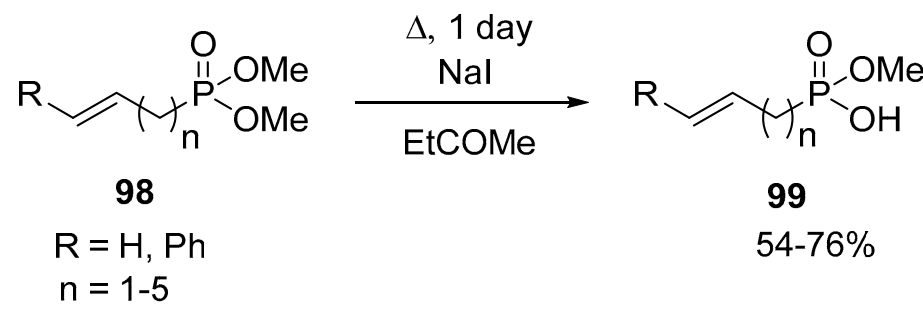

Scheme 63. Monodealkylation of phosphonates using NaI.

$\triangle, 24-150 \mathrm{~h}$<smiles>[R][X]C(=O)CC(=O)c1ccccc1</smiles>

$\mathrm{R}=\mathrm{H}, 4-\mathrm{Cl}, 4-\mathrm{Me}$

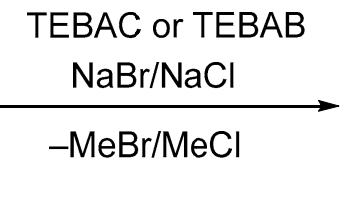

$R+$<smiles>[R][X]OP(=O)(CC(=O)c1ccccc1)O[Na]</smiles>

$50-95 \%$

Scheme 64. Monodealkylation of phosphonates (100) under phase-transfer catalytic conditions.

Diethyl phosphonates could also be monodealkylated at $80-100{ }^{\circ} \mathrm{C}$ for good yields using lithium bromide or chloride [184]. There is an example of the use of lithium triethylborohydride as the monodealkylating agent in the preparation of GABA analogue phosphonic acids (102) (Scheme 65) [185].

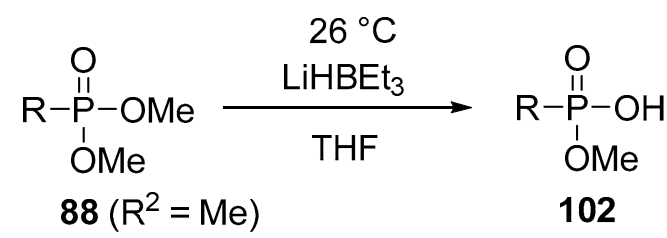

$\mathrm{R}=\mathrm{Me}, \mathrm{Bn}$

$90 \%$

Scheme 65. Selective monodealkylation using $\mathrm{LiHBEt}_{3}$.

In a few cases, the dealkylation could also be accomplished with amines, e.g., the monodealkylation of $H$-phosphonates was performed with tert-butylamine [54,55], but hydrazine could also be applied as a dealkylating agent [186].

\section{Conclusions}

$P$-acids have a significant role among drugs. Additionally, they have applications as herbicides and flame retardants as well. Hydrolysis is the most frequently used method to prepare $P$-acids that may be catalyzed by acids and bases. Comparing the two methods, it can be said that the alkaline hydrolysis takes place faster, and is less corrosive, but it is realized in two steps. The Na salt is formed in the first step, followed by the liberation of the free acid. While the acid-catalyzed hydrolysis may involve the cleavage of the $\mathrm{P}-\mathrm{O}$ bond $\left(\mathrm{A}_{\mathrm{Ac}} 2\right.$ mechanism) and that of the $\mathrm{C}-\mathrm{O}$ bond $\left(\mathrm{A}_{\mathrm{Al}} 1\right.$ mechanism) as well, the alkaline hydrolysis takes place via the cleavage of P-O bond. This explains why the 
isopropyl ester reacts faster than the methyl ester under acidic conditions, while in the basecatalyzed process, the former reacts considerably slower. The course of the reactions may be influenced by various factors, such as the temperature, solvent, $\mathrm{pH}$, and the substituents attached to the phosphorus atom. The steric hindrance decreases the reaction rate, while the electron-withdrawing effects either in the C- or OC-substituents attached to the $\mathrm{P}$ atom increase the reactivity. Another method to convert the esters to $P$-acids is cleavage by trimethylsilyl halides. This approach is selective and requires milder conditions. In addition to hydrolysis under conventional conditions, $\mathrm{MW}$-assisted variations were also elaborated, giving environmentally friendly and efficient accomplishments.

Through the examples discussed, it was shown that the hydrolysis of $P$-esters has not yet been explored fully, and generally that the reaction conditions have not been optimized. Despite these facts, especially on the basis of our own findings, this review may help us to get closer to a better understanding of this area of phosphorus chemistry. We advise the performance of the hydrolyses under acidic conditions using $0.5 \mathrm{~mL}$ of $c c . \mathrm{HCl}$ in $1 \mathrm{~mL}$ water to each $2 \mathrm{mmol}$ of the phosphinate, or to each $1 \mathrm{mmol}$ of the phosphonate.

Funding: This project was funded by the National Research, Development and Innovation Office (K134318).

Conflicts of Interest: The authors declare no conflict of interest.

\section{References}

1. Horsman, G.P.; Zechel, D.L. Phosphonate biochemistry. Chem. Rev. 2017, 117, 5704-5783. [CrossRef]

2. Falagas, M.E.; Vouloumanou, E.K.; Samonis, G.; Vardakas, K.Z. Fosfomycin. Clin. Microbiol. Rev. 2016, 29, 321-347. [CrossRef] [PubMed]

3. Pulwer, M.J.; Matthazor, T.M. A convenient synthesis of aminomethylphosphonic acid. Synth. Commun. 1986, 16, 733-739. [CrossRef]

4. De Clercq, E. Potential of acyclic nucleoside phosphonates in the treatment of DNA virus and retrovirus infections. Clin. Microbiol. Rev. 2003, 1, 21-43. [CrossRef]

5. Virieux, D.; Volle, J.-N.; Bakalara, N.; Pirat, J.-L. Synthesis and biological applications of phosphinates and derivatives. Top. Curr. Chem. 2014, 360, 39-114. [CrossRef]

6. $\quad$ Froestl, W.; Mickel, S.J.; von Sprecher, G.; Diel, P.J.; Hall, R.G.; Maier, L.; Strub, D.; Melillo, V.; Baumann, P.A.; Bernasconi, R.; et al. Phosphinic acid analogues of GABA. 2. Selective, orally active GABA $\mathrm{B}_{\mathrm{B}}$ antagonists. J. Med. Chem. 1995, 38, 3313-3331. [CrossRef]

7. Gavande, N.; Yamamoto, I.; Salam, N.K.; Ai, T.H.; Burden, P.M.; Johnston, G.A.R.; Hanrahan, J.R.; Chebib, M. Novel cyclic phosphinic acids as GABA $\mathrm{C}_{\mathrm{C}}$ receptor antagonists: Design, synthesis, and pharmacology. ACS Med. Chem. Lett. 2011, 2, 11-16. [CrossRef]

8. Reid, D.M.; Devogelaer, J.P.; Saag, K.; Roux, C.; Lau, C.S.; Reginster, J.Y.; Papanastasiou, P.; Ferreira, A.; Hartl, F.; Fashola, T.; et al. Zoledronic acid and risedronate in the prevention and treatment of glucocorticoid-induced osteoporosis (HORIZON): A multicentre, double-blind, double-dummy, randomised controlled trial. Lancet 2009, 373, 1253-1263. [CrossRef]

9. Black, D.M.; Cummings, S.R.; Karpf, D.B.; Cauley, J.A.; Thompson, D.E.; Nevitt, M.C.; Bauer, D.C.; Genant, H.K.; Haskell, W.L.; Marcus, R.; et al. Randomised trial of effect of alendronate on risk of fracture in women with existing vertebral fractures. Lancet 1996, 348, 1535-1541. [CrossRef]

10. Brücher, K.; Gräwert, T.; Konzuch, S.; Held, J.; Lienau, C.; Behrendt, C.; Illarionov, B.; Maes, L.; Bacher, A.; Wittlin, S.; et al. Prodrugs of reverse fosmidomycin analogues. J. Med. Chem. 2015, 58, 2025-2035. [CrossRef]

11. Verbrugghen, T.; Vandurm, P.; Pouyez, J.; Maes, L.; Wouters, J.; Van Calenbergh, S. Alpha-heteroatom derivatized analogues of 3-(acetylhydroxyamino)propyl phosphonic acid (FR900098) as antimalarials. J. Med. Chem. 2013, 56, 376-380. [CrossRef] [PubMed]

12. Zhang, Y.; Cao, R.; Yin, F.; Lin, F.Y.; Wang, H.; Krysiak, K.; No, J.H.; Mukkamala, D.; Houlihan, K.; Li, J.; et al. Lipophilic pyridinium bisphosphonates: Potent $\gamma \delta$ T cell stimulators. Angew. Chem. Int. Ed. 2010, 49, 1136-1138. [CrossRef]

13. Fonseca, E.M.B.; Trivella, D.B.B.; Scorsato, V.; Dias, M.P.; Bazzo, N.L.; Mandapati, K.R.; De Oliveira, F.L.; Ferreira-Halder, C.V.; Pilli, R.A.; Miranda, P.C.M.L.; et al. Crystal structures of the apo form and a complex of human LMW-PTP with a phosphonic acid provide new evidence of a secondary site potentially related to the anchorage of natural substrates. Bioorg. Med. Chem. 2015, 23, 4462-4471. [CrossRef] [PubMed]

14. Morita, C.T.; Jin, C.; Sarikonda, G.; Wang, H. Nonpeptide antigens, presentation mechanisms, and immunological memory of human $\mathrm{V} \gamma 2 \mathrm{~V} \delta 2 \mathrm{~T}$ cells: Discriminating friend from foe through the recognition of prenyl pyrophosphate antigens. Immunol. Rev. 2007, 215, 59-76. [CrossRef] 
15. Kramer, G.J.; Mohd, A.; Schwager, S.L.U.; Masuyer, G.; Acharya, K.R.; Sturrock, E.D.; Bachmann, B.O. Interkingdom pharmacology of angiotensin-I converting enzyme inhibitor phosphonates produced by actinomycetes. ACS Med. Chem. Lett. 2014, 5, 346-351. [CrossRef]

16. Myers, J.P.; Antoniou, M.N.; Blumberg, B.; Carroll, L.; Colborn, T.; Everett, L.G.; Hansen, M.; Landrigan, P.J.; Lanphear, B.P.; Mesnage, R.; et al. Concerns over use of glyphosate-based herbicides and risks associated with exposures: A consensus statement. Environ. Health 2016, 15, 1-13. [CrossRef] [PubMed]

17. Reiter, L.A.; Jones, B.P. Amide-assisted hydrolysis of $\beta$-carboxamido-substituted phosphinic acid esters metal ions, and appropriately substituted phosphinic responsible for promoting the cleavage of the phosphinic acid esters. J. Org. Chem. 1997, 62, 2808-2812. [CrossRef]

18. Nguyen, C.; Lee, M.; Kim, J. Relationship between structures of phosphorus compounds and flame retardancies of the mixtures with acrylonitrile—butadiene—styrene and ethylene—vinyl acetate copolymer. Polym. Adv. Technol. 2011, 22, 512-519. [CrossRef]

19. Kosolapoff, G.M.; Maier, L. Organic Phosphorus Compounds; J. Wiley \& Sons, Inc.: New York, NY, USA, 1972; Volume 4, pp. 264-273.

20. Jansa, P.; Baszczyňski, O.; Procházková, E.; Dračínský, M.; Janeba, Z. Microwave-assisted hydrolysis of phosphonate diesters: An efficient protocol for the preparation of phosphonic acids. Green Chem. 2012, 14, 2282-2288. [CrossRef]

21. Sevrain, C.M.; Berchel, M.; Couthon, H.; Jaffrès, P. Phosphonic acid: Preparation and applications. J. Org. Chem. 2017, 13, 2186-2213. [CrossRef]

22. Rahil, J.; Pratt, R.F. Intramolecular participation of the amide group in acid- and base-catalysed phosphonate monoester hydrolysis. J. Chem. Soc. Perkin Trans. 2 1991, 947-950. [CrossRef]

23. Kuzdin, Z.H.; Stec, W.J. Phosphohomocysteine derivates. Synthesis (Stuttg) 1980, 12, 1032-1034. [CrossRef]

24. Wȩglarz-Tomczak, E.; Berlicki, Ł.; Pawełczak, M.; Nocek, B.; Joachimiak, A.; Mucha, A. A structural insight into the P1 S1 binding mode of diaminoethylphosphonic and phosphinic acids, selective inhibitors of alanine aminopeptidases. Eur. J. Med. Chem. 2016, 117, 187-196. [CrossRef] [PubMed]

25. Hugot, N.; Roger, M.; Rueff, J.M.; Cardin, J.; Perez, O.; Caignaert, V.; Raveau, B.; Rogez, G.; Jaffrès, P.A. Copperfluorenephosphonate $\mathrm{Cu}\left(\mathrm{PO}_{3}-\mathrm{C}_{13} \mathrm{H}_{9}\right) \cdot \mathrm{H}_{2} \mathrm{O}$ : A layered antiferromagnetic hybrid. Eur. J. Inorg. Chem. 2016, $266-271$. [CrossRef]

26. Chauveau, E.; Marestin, C.; Mercier, R.; Brunaux, A.; Martin, V.; Nogueira, R.P.; Percheron, A.; Roche, V.; Waton, H. Phosphonic acid-containing polysulfones as anticorrosive layers. J. Appl. Polym. Sci. 2015, 132, 1-9. [CrossRef]

27. Fischer, T.; Duong, Q.N.; García Mancheño, O. Triazole-based anion-binding catalysis for the enantioselective dearomatization of N-heteroarenes with phosphorus nucleophiles. Chem. Eur. J. 2017, 23, 5983-5987. [CrossRef]

28. Sánchez-Moreno, M.J.; Gómez-Coca, R.B.; Fernández-Botello, A.; Ochocki, J.; Kotynski, A.; Griesser, R.; Sigel, H. Synthesis and acid-base properties of $\left(1 \mathrm{H}\right.$-benzimidazol-2-yl-methyl)phosphonate (Bimp $\left.{ }^{2-}\right)$. Evidence for intramolecular hydrogen-bond formation in aqueous solution between (N-1)H and the phosphonate group. Org. Biomol. Chem. 2003, 1, 1819-1826. [CrossRef]

29. Jaffrès, P.A.; Caignaert, V.; Villemin, D. A direct access to layered zirconium-phosphonate materials from dialkylphosphonates. Chem. Commun. 1999, 1997-1998. [CrossRef]

30. Griffiths, D.V.; Hughes, J.M.; Brown, J.W.; Caesar, J.C.; Swetnam, S.P.; Cumming, S.A.; Kelly, J.D. The synthesis of 1-amino-2hydroxy- and 2-amino-1-hydroxy-substituted ethylene-1,1-bisphosphonic acids and their N-methylated derivatives. Tetrahedron 1997, 53, 17815-17822. [CrossRef]

31. Kafarski, P.; Lejczak, B.; Szewczyk, J. Optically active 1-aminoalkanephosphonic acids. Dibenzoyl- L -tartaric anhydride as an effective agent for the resolution of racemic diphenyl 1-aminoalkanephosphonates. Can. J. Chem. 1983, 61, 2425-2430. [CrossRef]

32. Ikenberry, M.; Peña, L.; Wei, D.; Wang, H.; Bossmann, S.H.; Wilke, T.; Wang, D.; Komreddy, V.R.; Rillema, D.P.; Hohn, K.L. Acid monolayer functionalized iron oxide nanoparticles as catalysts for carbohydrate hydrolysis. Green Chem. 2014, 16, 836-843. [CrossRef]

33. Broeren, M.A.C.; De Waal, B.F.M.; Van Genderen, M.H.P.; Sanders, H.M.H.F.; Fytas, G.; Meijer, E.W. Multicomponent host-guest chemistry of carboxylic acid and phosphonic acid based guests with dendritic hosts: An NMR study. J. Am. Chem. Soc. 2005, 127, 10334-10343. [CrossRef] [PubMed]

34. Otaka, A.; Burke, T.R.; Smyth, M.S.; Nomizu, M.; Roller, P.P. Deprotection and cleavage methods for protected peptide resins containing 4-[(diethylphosphono)difluoromethyl]-D,L-phenylalanine residues. Tetrahedron Lett. 1993, 34, 7039-7042. [CrossRef]

35. Bunnett, J.F.; Edwards, J.O.; Wells, D.V.; Brass, H.J.; Curci, R. The hydrolysis of methyl methylarylphosphinates in perchloric acid solution. J. Org. Chem. 1973, 38, 2703-2707. [CrossRef]

36. Haake, P.; Hurst, G. Reactions of phosphinates. The acid-catalyzed and acid-inhibited hydrolysis of p-nitrophenyl diphenylphosphinate. J. Am. Chem. Soc. 1966, 88, 2544-2550. [CrossRef]

37. Kim, S.M.; Lee, M.; Lee, S.Y.; Park, E.; Lee, S.M.; Kim, E.J.; Han, M.Y.; Yoo, T.; Ann, J.; Yoon, S.; et al. Discovery of an orally bioavailable gonadotropin-releasing hormone receptor antagonist. J. Med. Chem. 2016, 59, 9150-9172. [CrossRef]

38. Yuan, C.; Li, S.; Liao, X. Studies on Organophosphorus Compounds. XXXVI* In alkaline hydrolysis. J. Phys. Org. Chem. 1990, 3, 48-54. [CrossRef]

39. Bergesen, K. Alkaline hydrolysis of the cis and trans isomers of the cyclic phosphinate: 1-Oxo-1-ethoxy-2,2,3,4,4-pentamethylphospha-cyclobutan. Acta Chem. Scand. 1967, 21, 1587-1591. [CrossRef]

40. Lin, Y.; Liu, J.T. Convenient synthesis of $\beta$-allenic $\alpha$-difluoromethylenephosphonic acid monoesters: Potential synthons for cyclic phosphate mimics. Chin. Chem. Lett. 2007, 18, 33-36. [CrossRef] 
41. Wróblewski, A.E.; Verkade, J.G. 1-Oxo-2-oxa-1-phosphabicyclo[2.2.2]octane: A new mechanistic probe for the basic hydrolysis of phosphate esters. J. Am. Chem. Soc. 1996, 118, 10168-10174. [CrossRef]

42. Palacios, F.; Alonso, C.; de los Santos, J.M. Synthesis of $\beta$-aminophosphonates and -phosphinates. Chem. Rev. 2005, 105, 899-931. [CrossRef] [PubMed]

43. Zhang, X.; Glunz, P.W.; Johnson, J.A.; Jiang, W.; Jacutin-Porte, S.; Ladziata, V.; Zou, Y.; Phillips, M.S.; Wurtz, N.R.; Parkhurst, B.; et al. Discovery of a highly potent, selective, and orally bioavailable macrocyclic inhibitor of blood coagulation factor VIIa-tissue factor complex. J. Med. Chem. 2016, 59, 7125-7137. [CrossRef] [PubMed]

44. Moss, R.A.; Morales-Rojas, H.; Vijayaraghavan, S.; Tian, J. Metal-cation-mediated hydrolysis of phosphonoformate diesters: Chemoselectivity and catalysis. J. Am. Chem. Soc. 2004, 126, 10923-10936. [CrossRef] [PubMed]

45. Mabey, W.; Mill, T. Critical review of hydrolysis of organic compounds in water under environmental conditions. J. Phys. Ref. Data 1978, 7, 383-415. [CrossRef]

46. Haake, P.; Diebert, C.E. Phosphinic acids and derivates. Pyrolytic elimination in phosphinate esters. J. Am. Chem. Soc. 1971, 93, 6931-6937. [CrossRef]

47. Zeuner, F.; Angermann, J.; Moszner, N. Synthesis of novel 2-vinylcyclopropane phosphonic acids. Synth. Commun. 2006, 36, 3679-3691. [CrossRef]

48. Åkerfeldt, K.S.; Bartlett, P.A. Synthesis and evaluation of glucose-ADP hybrids as inhibitors of hexokinase. J. Org. Chem. 1991, 56, 7133-7144. [CrossRef]

49. Alley, S.R.; Henderson, W. Synthesis and characterisation of ferrocenyl-phosphonic and -arsonic acids. J. Organomet. Chem. 2001, 637, 216-229. [CrossRef]

50. Smits, J.P.; Wiemer, D.F. Synthesis and reactivity of alkyl-1, 1, 1-trisphosphonate esters. J. Org. Chem. 2011, 76, 8807-8813. [CrossRef]

51. Green, O.M. A rapid dealkylation of phosphonate diester for the preparation of 4-phosphonomethylphenylalanine-containing peptides. Tetrahedron Lett. 1994, 35, 8081-8084. [CrossRef]

52. Jiménez-García, L.; Kaltbeitzel, A.; Pisula, W.; Gutmann, J.S.; Klapper, M.; Müllen, K. Phosphonated hexaphenylbenzene: A crystalline proton conductor. Angew. Chem. Int. Ed. 2009, 48, 9951-9953. [CrossRef]

53. Gauvry, N.; Mortier, J. Dealkylation of dialkyl phosphonates with boron tribromide. Synthesis (Stuttg) 2001, 4, 553-554. [CrossRef]

54. Bryant, D.E.; Kilner, C.; Kee, T.P. Facile one-pot mono-dealkylation of $H$-phosphonate esters in high yield. Inorg. Chim. Acta 2009, 362, 614-616. [CrossRef]

55. Imamura, M.; Hashimoto, H. Synthesis of novel CMP-NeuNAc analogues having a glycosyl phosphonate structure. Tetrahedron Lett. 1996, 37, 1451-1454. [CrossRef]

56. Georgiev, E.M.; Roundhillt, D.M. Dealkylation of phosphorus-containing alkylammonium salts formed by the interaction of phosphonic, methanephosphonic and phosphoric acid esters with diamines. Phosphorus Sulfur Silicon Relat. Elem. 1994, 92, 101-107. [CrossRef]

57. McKenna, C.E.; Higa, M.T.; Cheung, N.H.; McKenna, M.C. The facile dealkylation of phosphonic acid dialkyl esters by bromotrimethylsilane. Tetrahedron Lett. 1977, 2, 155-158. [CrossRef]

58. Dhawan, B.; Redmore, D. O-hydroxyaryl diphosphonic acids. J. Org. Chem. 1984, 49, 4018-4021. [CrossRef]

59. Rabinowitz, R. The reactions of phosphonic acid esters with acid chlorides. A very mild hydrolytic route. J. Org. Chem. 1963, 28, 2975-2978. [CrossRef]

60. Grothusen, J.R.; Bryson, P.K.; Zimmerman, J.K.; Brown, T.M. Hydrolysis of 4-nitrophenyl organophosphinates by arylester hydrolase from rabbit serum. J. Agric. Food Chem. 1986, 34, 513-515. [CrossRef]

61. Natchev, I.A. Synthesis, enzyme-substrate interaction, and herbicidal activity of phosphoryl analogues of glycine. Liebigs. Ann. Chem. 1988, 861-867. [CrossRef]

62. Kelly, S.J.; Butler, L.G. Enzymic hydrolysis of phosphonate esters. Biochem. Biophys. Res. Commun. 1975, 66, 316-321. [CrossRef]

63. Kelly, S.J.; Dardinger, D.E.; Butler, L.G. Hydrolysis of phosphonate esters catalyzed by 5 '-nucleotide phosphodiesterase. Biochemistry 1975, 14, 4983-4988. [CrossRef] [PubMed]

64. Becker, E.L.; Barbaro, J.F. The enzymatic hydrolysis of p-nitrophenyl ethyl phosphonates by mammalian plasmas. Biochem. Pharmacol. 1964, 13, 1219-1227. [CrossRef]

65. Agranoff, W. Hydrolysis of long-chain alkyl phosphates and phosphatidic acid by an enzyme purified from pig brain. J. Lipid Res. 1962, 3, 190-196. [CrossRef]

66. Alvarez, E.F. The kinetics and mechanism of the hydrolysis of phosphoric acid esters by potato acid phosphatase. Biochim. Biophys. Acta 1962, 59, 663-672. [CrossRef]

67. King, E.J.; Delory, G.E. The rates of enzymic hydrolysis of phosphoric esters. Biochem. J. 1939, 33, 1185-1190. [CrossRef]

68. Walker, P.G.; King, E.J. The rate of enzymic hydrolysis of phosphoric esters. 3. Carboxy-substituted phenyl phosphates. Biochem. J. 1950, 47, 93-95. [CrossRef]

69. Whitfeld, P.R.; Heppel, L.A.; Markham, R. The enzymic hydrolysis of ribonucleoside-2' $: 3^{\prime}$ phosphates. Biochem. J. 1955, 60, 15-19. [CrossRef] [PubMed]

70. Mäkinen, K.K. Hydrolysis of phosphates by enzyme preparations derived from carious dentine, bacterial plaque and saliva. Caries Res. 1970, 4, 14-22. [CrossRef] 
71. O'Brien, P.J.; Herschlag, D. Alkaline phosphatase revisited: Hydrolysis of alkyl phosphates. Biochemistry 2002, 41, 3207-3225. [CrossRef]

72. Ray, R.; Boucher, L.J.; Broomfield, C.A.; Lenz, D.E. Specific soman-hydrolyzing enzyme activity in chlonal neuronal cell culture. Biochim. Biophys. Acta 1988, 967, 373-381. [CrossRef]

73. Gabdrakhamanov, D.R.; Samarkina, D.A.; Semenov, V.E.; Saifina, L.F.; Valeeva, F.G.; Reznik, V.S.; Zakharova, L.Y. Substrate specific nanoreactors based on pyrimidine-containing amphiphiles of various structures for cleavage of phosphonates. Phosphorus Sulfur Silicon Relat. Elem. 2016, 191, 1673-1675. [CrossRef]

74. Tsubouchi, A.; Bruice, T.C. Remarkable $\left(\sim 10^{13}\right)$ rate enhancement in phosphonate ester hydrolysis catalyzed by two metal ions. J. Am. Chem. Soc. 1994, 116, 11614-11615. [CrossRef]

75. Schneider, H.-J.; Rammo, J.; Hettich, R. Catalysis of the hydrolysis of phosphoric acid diesters by lanthanide ions and the influence of ligands. Angew. Chem. Int. Ed. 1993, 32, 1716-1719. [CrossRef]

76. Joseph, S.K.; Esch, T.; Bonner, W.D. Hydrolysis of inositol phosphates by plant cell extracts. Biochem. J. 1989, 264, 851-856. [CrossRef]

77. Samarkina, D.A.; Gabdrakhmanov, D.R.; Semenov, V.E.; Valeeva, F.G.; Gubaidullina, L.M.; Zakharova, L.Y.; Reznik, V.S.; Konovalov, A.I. Self-assembling catalytic systems based on new amphiphile containing purine fragment, exhibiting substrate specificity in hydrolysis of phosphorus acids esters. Russ. J. Gen. Chem. 2016, 86, 656-660. [CrossRef]

78. Keglevich, G.; Kovács, A.; Tőke, L.; Újszászy, K.; Argay, G.; Czugler, M.; Kálmán, A. P-substituted 3-phosphabicyclo[3.1.0] hexane 3-oxides from diastereoselective substitution at phosphorus. Heteroatom Chem. 1993, 4, 329-335. [CrossRef]

79. Weyl, T. Houben-Weyl Methoden der Organischen Chemie; ASC Publications: New York, NY, USA, 1982; Volume 2, pp. 310-313.

80. Cook, R.D.; Abbas, K.A. The acid catalyzed hydrolysis of methyl dialkylphosphinates. Tetrahedron Lett. 1973, 14, 519-520. [CrossRef]

81. Abbas, K.A.; Cook, R.D. The acid-catalyzed hydrolysis of phosphinates. II. The mechanism of hydrolysis of methyl dialkylphosphinates. Tetrahedron Lett. 1975, 41, 3559-3562. [CrossRef]

82. Abbas, K.A.; Cook, R.D. The acid-catalyzed hydrolysis of phosphinates. III. The mechanism of hydrolysis of methyl and benzyl dialkylphosphinates. Can. J. Chem. 1977, 55, 3740-3750. [CrossRef]

83. Cook, R.D.; Metni, M. The acid-catalyzed hydrolysis of phosphinates. IV. Pentacoordinate intermediate formation during hydrolysis of a phosphinothionate. Can. J. Chem. 1985, 63, 3155-3159. [CrossRef]

84. Tcarkova, K.V.; Artyushin, O.I.; Bondarenko, N.A. Synthetic routes to bis(3-aminophenyl) phosphinic acid. Phosphorus Sulfur Silicon Relat. Elem. 2016, 191, 1520-1522. [CrossRef]

85. Wang, Y.; Wang, Y.; Yu, J.; Miao, Z.; Chen, R. Stereoselective synthesis of $\alpha$-amino(phenyl)methyl(phenyl)phosphinic acids with O-pivaloylated D-galactoslamine as chiral auxiliary. Chem. Eur. J. 2009, 15, 9290-9293. [CrossRef] [PubMed]

86. Rossi, J.C.; Marull, M.; Larcher, N.; Taillades, J.; Pascal, R.; van der Lee, A.; Gerbier, P. A recyclable chiral auxiliary for the asymmetric syntheses of $\alpha$-aminonitriles and $\alpha$-aminophosphinic derivatives. Tetrahedron Asymmetry 2008, 19, 876-883. [CrossRef]

87. Dingwall, J.G.; Ehrenfreund, J.; Hall, R.G. Diethoxymethylphosphonites and phosphinates. Intermediates for thesynthesis of $\alpha, \beta-$ and $\gamma$-aminoalkylphosphonous acids. Tetrahedron 1989, 45, 3787-3808. [CrossRef]

88. Cristau, H.J.; Hervé, A.; Virieux, D. Synthesis of new $\alpha$ or $\gamma$-functionalized hydroxymethylphosphinic acid derivatives. Tetrahedron 2004, 60, 877-884. [CrossRef]

89. Dennis, E.A.; Westheimer, F.H. The rates of hydrolysis of esters of cyclic phosphinic acids. J. Am. Chem. Soc. 1966, 88, 3431-3432. [CrossRef] [PubMed]

90. Keglevich, G.; Rádai, Z.; Harsági, N.; Szigetvári, Á.; Kiss, N.Z. A study on the acidic hydrolysis of cyclic phosphinates: 1-Alkoxy-3phospholene 1-oxides, 1-ethoxy-3-methylphospholane 1-oxide, and 1-ethoxy-3-methyl-1,2,3,4,5,6-hexahydrophosphinine 1-oxide. Heteroatom Chem. 2017, 28, e21394. [CrossRef]

91. Harsági, N.; Szőllősi, B.; Kiss, N.Z.; Keglevich, G. MW irradiation and ionic liquids as green tools in hydrolyses and alcoholyses. Green Process. Synth. 2021, 10, 1-10. [CrossRef]

92. Hudson, R.F.; Keay, L. The hydrolysis of phosphonate esters. J. Chem. Soc. 1956, 2463-2469. [CrossRef]

93. Keglevich, G.; Grün, A.; Bölcskei, A.; Drahos, L.; Kraszni, M.; Balogh, G.T. Synthesis and proton dissociation properties of arylphosphonates: A microwave-assisted catalytic Arbuzov reaction with aryl bromides. Heteroatom Chem. 2012, 23, 574-582. [CrossRef]

94. Harsági, N.; Rádai, Z.; Kiss, N.Z.; Szigetvári, A.; Keglevich, G. Two step acidic hydrolysis of dialkyl arylphosphonates. Mendeleev Commun. 2020, 30, 38-39. [CrossRef]

95. Desai, J.; Wang, Y.; Wang, K.; Malwal, S.R.; Oldfield, E. Isoprenoid biosynthesis inhibitors targeting bacterial cell growth. Chem. Med. Chem. 2016, 11, 2205-2215. [CrossRef]

96. Kolodyazhnaya, A.O.; Kukhar, V.P.; Kolodyazhnyi, O.I. Organic catalysis of Phospha-Aldol condensation. Russ. J. Gen. Chem. 2008, 78, 2043-2051. [CrossRef]

97. Kiss, N.Z.; Henyecz, R.; Keglevich, G. Continuous flow esterification of a $H$-phosphinic acid, and transesterification of $H$ phosphinates and $H$-phosphonates under microwave conditions. Molecules 2020, 25, 719. [CrossRef] [PubMed]

98. Ósapay, G.; Szilágyi, I.; Seres, J. Conversion of amino acids and dipeptides into their phosphonic analogs. Tetrahedron 1987, 43, 2977-2983. [CrossRef] 
99. Dabrowska, E.; Burzyńska, A.; Mucha, A.; Matczak-Jon, E.; Sawka-Dobrowolska, W.; Berlicki, Ł.; Kafarski, P. Insight into the mechanism of three component condensation leading to aminomethylenebisphosphonates. J. Organomet. Chem. 2009, 694, 3806-3813. [CrossRef]

100. Kannan Sivaraman, K.; Paiardini, A.; Sieńczyk, M.; Ruggeri, C.; Oellig, C.A.; Dalton, J.P.; Scammells, P.J.; Drag, M.; McGowan, S. Synthesis and structure-activity relationships of phosphonic arginine mimetics as inhibitors of the M1 and M17 aminopeptidases from plasmodium falciparum. J. Med. Chem. 2013, 56, 5213-5217. [CrossRef]

101. Kuzdin, Z.H.; Stec, W.J. Synthesis of 1-aminoalkenephosphonates via thio-ureidoalkanephosphonates. Synthesis (Stuttg.) 1978, 6, 469-472. [CrossRef]

102. Jansa, P.; Hradil, O.; Baszczyňski, O.; Dračínský, M.; Klepetářová, B.; Holý, A.; Balzarini, J.; Janeba, Z. An efficient microwaveassisted synthesis and biological properties of polysubstituted pyrimidinyl- and 1,3,5-triazinylphosphonic acids. Tetrahedron 2012, 68, 865-871. [CrossRef] [PubMed]

103. Cadogan, J.I.G.; Eastlick, D.T. Neighbouring group-induced phosphorus-oxygen fission in acidic hydrolysis of phosphonates. J. Chem. Soc. 1970, 1546-1547. [CrossRef]

104. Cook, R.D.; Diebert, C.E.; Schwarz, W.; Turley, P.C.; Haake, P. Mechanism of nucleophilic displacement at phosphorus in the alkaline hydrolysis of phosphinate esters. J. Am. Chem. Soc. 1973, 95, 8088-8096. [CrossRef]

105. Clarke, F.B.; Westheimer, F.H. Substituted 1-oxyphosphole. J. Am. Chem. Soc. 1971, 93, 4541-4545. [CrossRef]

106. Hong, H.J.; Lee, J.; Bae, A.R.; Um, I.H. Kinetics and reaction mechanism for alkaline hydrolysis of Y-substituted-phenyl diphenylphosphinates. Bull. Korean Chem. Soc. 2013, 34, 2001-2005. [CrossRef]

107. Cevasco, G.; Thea, S. The Quest for carbanion-promoted dissociative pathways in the hydrolysis of aryl phosphinates. J. Chem. Soc. Perkin Trans. 2 1993, 1103-1106. [CrossRef]

108. Cevasco, G.; Thea, S. Kinetic study on the alkaline hydrolysis of some tetracoordinate P(V) esters of 2, 4-Dinitrophenol. J. Chem. Soc. Perkin Trans. 2 1994, 53, 1103-1105. [CrossRef]

109. Kluger, R.; Taylor, S.D. Endocyclic cleavage in the alkaline hydrolysis of the cyclic phosphonate methyl propylphostonate: Dianionic intermediates and barriers to pseudorotation. J. Am. Chem. Soc. 1991, 113, 5714-5719. [CrossRef]

110. Qi, N.; Zhang, N.; Allu, S.R.; Gao, J.; Guo, J.; He, Y. Insertion of arynes into P-O bonds: One-step simultaneous construction of C-P and C-O bonds. Org. Lett. 2016, 18, 6204-6207. [CrossRef]

111. Hawes, W.; Trippett, S. Steric hindrance in the alkaline hydrolysis of phosphinate esters. Chem. Commun. 1968, 577-578. [CrossRef]

112. Rahil, J.; Haake, P. Rates and mechanism of the alkaline hydrolysis of a sterically hindered phosphinate ester. Partial reaction by nucleophilic attack at carbon. J. Org. Chem. 1981, 46, 3048-3052. [CrossRef]

113. Haake, P.; Schwartz, W.; McCoy, D.R. Phosphinic acids and derivates 6. Esters of dialkylphosphinic acids. Tetrahedron Lett. 1968, 9, 5251-5254. [CrossRef]

114. Aksnes, G.; Bergesen, K. Rate studies of cyclic phosphinates, phosphonates and phosphates. Acta Chem. Scand. 1966, 20 , $2508-2514$. [CrossRef]

115. Allen, D.W.; Hutley, B.G.; Mellor, M.T.J. The chemistry of heteroarylphosphorus compounds. Part 10. Synthesis and kinetics of alkaline hysrolysis of heterarylphosphinate esters and hydrolysis of heteroarylphosphine oxides. J. Chem. Soc. Perkin Trans. 2 1977, 1705-1708. [CrossRef]

116. Williams, A.; Naylor, R.A. Hydrolysis of phosphinic esters: General- base catalysis by imidazole. J. Chem. Soc 1971, 10, 1967-1972. [CrossRef]

117. Cook, R.D.; Rahhal-Arabi, L. The kinetics of the alkaline hydrolysis of aryl diphenylphoshpinothioates; the significance for the mechanism of displacement at phosphorus. Tetrahedron Lett. 1985, 26, 3147-3150. [CrossRef]

118. Cook, R.D.; Farah, S.; Ghawi, L.; Itani, A.; Rahil, J. The influence of the changing of $\mathrm{P}=\mathrm{O}$ to $\mathrm{P}=\mathrm{S}$ and $\mathrm{P}-\mathrm{O}-\mathrm{R}$ to $\mathrm{P}-\mathrm{S}-\mathrm{R}$ on the reactivity of phosphinate esters under alkaline hydrolysis conditions. Can. J. Chem. 1986, 64, 1630-1637. [CrossRef]

119. Blaskó, A.; Bunton, C.A.; Hong, Y.S.; Mhala, M.M.; Moffatt, J.R.; Wright, S. Micellar rate effects on reactions of hydroxide ion with phosphinate and thiophosphinate esters. J. Phys. Org. Chem. 1991, 4, 618-628. [CrossRef]

120. Aksnes, G.; Songstad, J. Alkaline hydrolysis of diethyl esters of alkylphosphonic acids and some chloro-substituted derivatives. Acta Chem. Scand. 1965, 19, 893-897. [CrossRef]

121. Kim, B.-S.; Kim, B.-T.; Hwang, K.-J. A practical method to cleave diphenyl phosphonate esters to their corresponding phosphonic acids in one step. Bull. Korean Chem. Soc. 2009, 30, 1391-1393. [CrossRef]

122. Freeman, G.A.; Rideout, J.L.; Miller, W.H.; Reardon, J.E. 3'-Azido-3' $5^{\prime}$-dideoxythymidine-5' -methylphosphonic acid diphosphate: Synthesis and HIV-1 reverse transcriptase inhibition. J. Med. Chem. 1992, 35, 3192-3196. [CrossRef]

123. Yuan, C.; Li, S.; Liao, X. Studies on organophosphorus compounds XXXI. Alkaline hydrolysis of 2-alkyl-2-oxo-1,3,2-dioxaphosphorinane and -phosphepane. Phosphorous Sulfur Relat. Elem. 1988, 37, 205-212. [CrossRef]

124. Behrman, E.J.; Biallas, M.J.; Brass, H.J.; Edwards, J.O.; Isaks, M. Reactions of phosphonic acid esters with nucleophiles I. Hydrolysis. J. Org. Chem. 1970, 35, 3063-3069. [CrossRef]

125. Kóšiová, I.; Točík, Z.; Buděšínský, M.; Šimák, O.; Liboska, R.; Rejman, D.; Pačes, O.; Rosenberg, I. Methyl 4-toluenesulfonyloxymethylphosp a new and versatile reagent for the convenient synthesis of phosphonate-containing compounds. Tetrahedron Lett. 2009, 50, 6745-6747. [CrossRef] 
126. Zakharova, L.Y.; Valeeva, F.G.; Kudryavtseva, L.A.; Konovalov, A.I.; Zakharchenko, N.L.; Zuev, Y.F.; Fedotov, V.D. Alkaline hydrolysis of ethyl p-nitrophenyl chloromethylphosphonate in the reverse micellar AOT-decane-water system. Russ. Chem. Bull. 1999, 48, 2240-2244. [CrossRef]

127. Zakharova, L.Y.; Kudryavtsev, D.B.; Valeeva, F.G.; Kudryavtseva, L.A. Inhibition of alkaline hydrolysis of ethyl $p$-nitrophenyl (cloromethyl)phosphonate in the system cationic surfactant-water-electrolyte. Russ. J. Gen. Chem. 2002, 72, 1215-1221. [CrossRef]

128. Kehler, J.; Hansen, H.I.; Sanchez, C. Novel phosphinic and phosphonic acid analogues of the anticonvulsant valproic acid. Bioorg. Med. Chem. Lett. 2000, 10, 2547-2548. [CrossRef]

129. Dunne, K.S.; Bisaro, F.; Odell, B.; Paris, J.-M.; Gouverneur, V. Diastereoselective ring-closing metathesis: Synthesis of $P$-stereogenic phosphinates from prochiral phosphinic acid derivatives. J. Org. Chem. 2005, 70, 10803-10809. [CrossRef]

130. Hum, G.; Wooler, K.; Lee, J.; Taylor, S.D. Cyclic five-membered phosphinate esters as transition state analogues for obtaining phosphohydrolase antibodies. Can. J. Chem. 2000, 78, 642-655. [CrossRef]

131. Årstad, E.; Hoff, P.; Skattebøl, L.; Skretting, A.; Breistøl, K. Studies on the synthesis and biological properties of non-carrier-added [125I and 131I]-labeled arylalkylidenebisphosphonates: Potent bone-seekers for diagnosis and therapy of malignant osseous lesions. J. Med. Chem. 2003, 46, 3021-3032. [CrossRef]

132. Brunet, E.; Alhendawi, H.M.H.; Cerro, C.; de la Mata, M.J.; Juanes, O.; Rodríguez-Ubis, J.C. Easy $\gamma$-to- $\alpha$ transformation of zirconium phosphate/polyphenylphosphonate salts: Porosity and hydrogen physisorption. Chem. Eng. J. 2010, 158, 333-344. [CrossRef]

133. Demmer, C.S.; Krogsgaard-Larsen, N.; Bunch, L. Review on modern advances of chemical methods for the introduction of a phosphonic acid group. Chem. Rev. 2011, 111, 7981-8006. [CrossRef]

134. Frantz, R.; Carré, F.; Durand, J.O.; Lanneau, G.F. New phosphonates containing a $\pi$-conjugated ferrocenyl unit. New, J. Chem. 2001, 25, 188-190. [CrossRef]

135. Rudinskas, A.J.; Hullar, T.L.; Salvador, R.L. Phosphonic acid chemistry. 2. Studies on the Arbuzov reaction of 1-bromo-4,4diethoxy-2-butyne and Rabinowitch method of dealkylation of phosphonate diesters using chloro- and bromotrimethylsilane. J. Org. Chem. 1977, 42, 2771-2776. [CrossRef]

136. Jaffrès, P.-A.; Bar, N.; Villemin, D. Phosphonation of 1,1'-binaphthalene-2,2'-diol ( BINOL ): Synthesis of (R)-and (S)-2,2'-dihydroxy1,1'-binaphthalene-6,6'-diyldiphosphonic acid. J. Chem. Soc. Perkin Trans. 1 1998, 2083-2089. [CrossRef]

137. McKenna, C.E.; Schmidhuser, J. Functional selectivity in phosphonate ester dealkylation with bromotrimethylsilane. J. Chem. Soc. 1979, 739. [CrossRef]

138. Błazewska, K.M. McKenna reaction-Which oxygen attacks bromotrimethylsilane? J. Org. Chem. 2014, 79, 408-412. [CrossRef] [PubMed]

139. Blackburn, G.M.; Ingleson, D. Specific dealkylation of phosphonate esters using iodotrimethylsilane. J. Chem. Soc. Chem. Commun. 1978, 870-871. [CrossRef]

140. Blackburn, G.M.; Ingleson, D. The dealkylation of phosphate and phosphonate esters by iodotrimethyl-silane: A mild and selective procedure. J. Chem. Soc. Chem. Commun. 1980, 6, 1150-1153. [CrossRef]

141. Gutierrez, A.J.; Prisbe, E.J.; Rohloff, J.C. Dealkylation of phosphonate esters with chlorotrimethylsilane. Nucleosides Nucleotides and Nucleic Acids 2001, 20, 1299-1302. [CrossRef] [PubMed]

142. He, H.; Liu, X.; Hu, L.; Wang, S.; Liu, Z. Synthesis and dealkylation of 1-(dichloro-phenoxyacetoxy) alkyl phosphonates. Phosphorus Sulfur Silicon Relat. Elem. 1999, 144, 633-636. [CrossRef]

143. Morita, T.; Okamoto, Y.; Sakurai, H. Dealkylation reaction of acetals, phosphonate and phosphate esters with chlorotrimethylsilane/metal halide reagent in acetonitrile, and its application to the synthesis of phosphonic acids and vinyl phosphates. Bull. Chem. Soc. Jpn. 1981, 54, 267-273. [CrossRef]

144. Machida, Y.; Nomoto, S.; Saito, I. A useful method for the delakylation of dialkyl phosphonates. Synth. Commun. 1979, 9, 97-102. [CrossRef]

145. Boutevin, B.; Hamoui, B.; Parisi, J. New diethyl phosphonoalkyl acrylates and their reactivity in copolimerization. Polym. Bull. 1993, 30, 243-248. [CrossRef]

146. Regitz, M.; Martin, R. Untersuchungen an diazoverbindungen und aziden-il: Tert-butylammoniumsalze von $\alpha$-diazophosphinund $\alpha$-diazophosphonsäuren. Tetrahedron 1985, 41, 819-824. [CrossRef]

147. Cermak, D.M.; Cermak, S.C.; Deppe, A.B.; Durham, A.L. Novel $\alpha$-hydroxy phosphonic acids via castor oil. Ind. Crops Prod. 2012, 37, 394-400. [CrossRef]

148. Deemie, R.W.; Fettinger, J.C.; Knight, D.A. Synthesis and characterization of an organometallic phosphonic acid: X-ray crystal structure of. J. Organomet. Chem. 1997, 538, 257-259. [CrossRef]

149. Meziane, D.; Hardouin, J.; Elias, A.; Guénin, E.; Lecouvey, M. Microwave Michaelis-Becker synthesis of diethyl phosphonates, tertaethyl diphosphonates, and their total or partial dealkylation. Heteroat. Chem. 2009, 20, 369-377. [CrossRef]

150. Gan, X.M.; Rapko, B.M.; Fox, J.; Binyamin, I.; Pailloux, S.; Duesler, E.N.; Paine, R.T. A three-dimensional framework structure constructed from 2-(2-pyridyl-N-oxide) ethylphosphonic acid and $\mathrm{Nd}(\mathrm{III})$. Inorg. Chem. 2006, 45, 3741-3745. [CrossRef]

151. Ganguly, S.; Mague, J.T.; Roundhill, D.M. Synthesis and characterization of new water solube tertiary phosphines having terminally substituted alkylene sulfonate or alkylene phosphonate chains. Inorg. Chem. 1992, 31, 3500-3501. [CrossRef]

152. Kadina, A.P.; Kashemirov, B.A.; Oertell, K.; Batra, V.K.; Wilson, S.H.; Goodman, M.F.; McKenna, C.E. Two scaffolds from two flips: $(\alpha, \beta) /(\beta, \gamma) \mathrm{CH}_{2} / \mathrm{NH}$ "Met-Im" analogues of dTTP. Org. Lett. 2015, 17, 2586-2589. [CrossRef] 
153. Klein, Y.M.; Willgert, M.; Prescimone, A.; Constable, E.C.; Housecroft, C.E. Positional isomerism makes a difference: Phosphonic acid anchoring ligands with thienyl spacers in copper(I)-based dye-sensitized solar cells. Dalton Trans. 2016, 45, 4659-4672. [CrossRef]

154. Marma, M.S.; Khawli, L.A.; Harutunian, V.; Kashemirov, B.A.; McKenna, C.E. Synthesis of $\alpha$-fluorinated phosphonoacetate derivatives using electrophilic fluorine reagents: Perchloryl fluoride versus 1-chloromethyl-4- fluoro-1,4-diazoniabicyclo[2.2.2]octane bis(tetrafluoroborate) (Selectfluor ${ }^{\circledR}$ ). J. Fluor. Chem. 2005, 126, 1467-1475. [CrossRef]

155. Marquick, A.L.; Montero, J.L.; Lebrun, A.; Barragan-Montero, V. Straightforward synthesis towards mono and bis-phosphonic acid functionalised $\beta$-cyclodextrins. Tetrahedron 2015, 71, 1616-1621. [CrossRef]

156. Matthiesen, R.A.; Wills, V.S.; Metzger, J.I.; Holstein, S.A.; Wiemer, D.F. Stereoselective synthesis of homoneryl and homogeranyl triazole bisphosphonates. J. Org. Chem. 2016, 81, 9438-9442. [CrossRef] [PubMed]

157. Rudolf, B.; Salmain, M.; Palusiak, M.; Zakrzewski, J. The phospha-Michael addition of dimethyl- and diphenylphosphites to the $\eta 1-\mathrm{N}-$ maleimidato ligand: Inhibition of serine hydrolases by half-sandwich metallocarbonyl azaphosphonates. J. Organomet. Chem. 2009, 694, 908-915. [CrossRef]

158. Taylor, S.D.; Mirzaei, F.; Bearne, S.L. An unsymmetrical approach to the synthesis of bismethylene triphosphate analogues. Org. Lett. 2006, 8, 4243-4246. [CrossRef]

159. Rueff, J.-M.; Perez, O.; Pautrat, A.; Barrier, N.; Hix, G.B.; Hernot, S.; Couthon-Gourvés, H.; Jaffrés, P.-A. Structural study of hydrated/dehydrated manganese thiophene-2,5-diphosphonate metal organic frameworks, $\mathrm{Mn}_{2}\left(\mathrm{O}+\mathrm{P}-\mathrm{C}_{4} \mathrm{H}_{2} \mathrm{~S}_{9} \mathrm{PO}_{3}\right)^{*} 2 \mathrm{H}_{2} \mathrm{O}$. Inorg Chem. 2012, 51, 10251-10261. [CrossRef]

160. Wanat, P.; Walczak, S.; Wojtczak, B.A.; Nowakowska, M.; Jemielity, J.; Kowalska, J. Ethynyl, 2-propynyl, and 3-butynyl Cphosphonate analogues of nucleoside di- and triphosphates: Synthesis and reactivity in CuAAC. Org. Lett. 2015, 17, $3062-3065$. [CrossRef]

161. Liu, D.; Xu, X.; Su, Y.; He, Z.; Xu, J.; Miao, Q. Self-assembled monolayers of phosphonic acids with enhanced surface energy for high-performance solution-processed N-channel organic thin-film transistors. Angew. Chemie Int. Ed. 2013, 52, 6222-6227. [CrossRef]

162. Lejeune, N.; Dez, I.; Jaffrès, P.A.; Lohier, J.F.; Madec, P.J.; Santos, J.S.D.O. Synthesis, crystal structure and thermal properties of phosphorylated cyclotriphosphazenes. Eur. J. Inorg. Chem. 2008, 138-143. [CrossRef]

163. Liu, X.; Adams, H.; Blackburn, G.M. Synthesis of novel 'supercharged' analogues of pyrophosphoric acid. Chem. Commun. 1998, 2619-2620. [CrossRef]

164. Lee, S.I.; Yoon, K.H.; Song, M.; Peng, H.; Page, K.A.; Soles, C.L.; Yoon, D.Y. Structure and properties of polymer electrolyte membranes containing phosphonic acids for anhydrous fuel cells. Chem. Mater. 2012, 24, 115-122. [CrossRef]

165. Rolland, O.; Griffe, L.; Poupot, M.; Maraval, A.; Ouali, A.; Coppel, Y.; Fournié, J.J.; Bacquet, G.; Turrin, C.O.; Caminade, A.M.; et al. Tailored control and optimisation of the number of phosphonic acid termini on phosphorus-containing dendrimers for the ex-vivo activation of human monocytes. Chem. Eur. J. 2008, 14, 4836-4850. [CrossRef] [PubMed]

166. Park, J.; Leung, C.Y.; Matralis, A.N.; Lacbay, C.M.; Tsakos, M.; Fernandez De Troconiz, G.; Berghuis, A.M.; Tsantrizos, Y.S. Pharmacophore mapping of thienopyrimidine-based monophosphonate (ThP-MP) inhibitors of the human farnesyl pyrophosphate synthase. J. Med. Chem. 2017, 60, 2119-2134. [CrossRef] [PubMed]

167. Pailloux, S.; Shirima, C.E.; Smith, K.A.; Duesler, E.N.; Paine, R.T.; Williams, N.J.; Hancock, R.D. Synthesis and reactivity of (benzoxazol-2-ylmethyl)phosphonic acid. Inorg. Chem. 2010, 49, 9369-9379. [CrossRef]

168. Opper, K.L.; Fassbender, B.; Brunklaus, G.; Spiess, H.W.; Wagener, K.B. Polyethylene functionalized with precisely spaced phosphonic acid groups. Macromolecules 2009, 42, 4407-4409. [CrossRef]

169. Turrin, C.O.; Hameau, A.; Caminade, A.M. Application of the Kabachnik-Fields and Moedritzer-Irani procedures for the preparation of bis(phosphonomethyl)amino- and bis[(dimethoxyphosphoryl)-methyl] amino-terminated poly(ethylene glycol). Synthesis 2012, 44, 1628-1630. [CrossRef]

170. Tulsi, N.S.; Downey, A.M.; Cairo, C.W. A protected l-bromophosphonomethylphenylalanine amino acid derivative (BrPmp) for synthesis of irreversible protein tyrosine phosphatase inhibitors. Bioorg. Med. Chem. 2010, 18, 8679-8686. [CrossRef] [PubMed]

171. Chougrani, K.; Niel, G.; Boutevin, B.; David, G. Regioselective ester cleavage during the preparation of bisphosphonate methacrylate monomers. Beilstein J. Org. Chem. 2011, 7, 364-368. [CrossRef]

172. Houghton, S.R.; Melton, J.; Fortunak, J.; Brown Ripid, D.H.; Boddy, C.N. Rapid, mild method for phosphonate diester hydrolysis: Development of a one-pot synthesis of tenofovir disoproxil fumarate from tenofovir diethyl ester. Tetrahedron 2010, 66, 8137-8144. [CrossRef]

173. Kim, S.; Hong, J.H. Synthesis and anti-HIV activity of novel $2^{\prime}$-deoxy-2'- $\beta$-fluoro-threosyl nucleoside phosphonic acid analogues. Nucleosides Nucleotides Nucleic Acids 2015, 34, 815-833. [CrossRef]

174. Salomon, C.J.; Breuer, E. Efficient and selective dealkylation of phosphonate dilsopropyl esters using Me 3 SiBr. Tetrahedron Lett. 1995, 36, 6759-6760. [CrossRef]

175. Dang, Q.; Brown, B.S.; Liu, Y.; Rydzewski, R.M.; Robinson, E.D.; Van Poelje, P.D.; Reddy, M.R.; Erion, M.D. Fructose-1,6bisphosphatase inhibitors. 1. Purine phosphonic acids as novel AMP mimics. J. Med. Chem. 2009, 52, 2880-2898. [CrossRef] [PubMed] 
176. Kruithof, C.A.; Dijkstra, H.P.; Lutz, M.; Spek, A.L.; Egmond, M.R.; Klein Gebbink, R.J.M.; Van Koten, G. Non-tethered organometallic phosphonate inhibitors for lipase inhibition: Positioning of the metal center in the active site of cutinase. Eur. J. Inorg. Chem. 2008, 4425-4432. [CrossRef]

177. Mortier, J.; Gridnev, I.D.; Fortineau, A.D. Synthesis of N-alkyl/aryl- $\alpha / \beta$-aminoalkylphosphonic acids from organodichloroboranes and $\alpha / \beta$-azidoalkylphosphonates via polyborophosphonates. Org. Lett. 1999, 1, 981-984. [CrossRef]

178. Nitta, Y.; Yasushi, A. The selective dealkylation of mixed esters of phosphoric acid and phenylphosphonic acid using cation exchange resin. Chem. Pharm. Bull. 1986, 34, 3121-3129. [CrossRef]

179. Weller, S.W.; Choksi, B.C.; Sanyal, S.K. Catalytic Dealkylation of esters acid-catalyzed dealkylation of diethyl ethylphosphonate. Ind. Eng. Chem. Prod. Res. Dev. 1971, 10, 38-42. [CrossRef]

180. André, V.; Lahrache, H.; Robin, S.; Rousseau, G. Reaction of unsaturated phosphonate monoesters with bromo- and iodo(biscollidine) hexafluorophosphates. Tetrahedron 2007, 63, 10059-10066. [CrossRef]

181. Chi, G.; Nair, V.; Semenova, E.; Pommier, Y. A novel diketo phosphonic acid that exhibits specific, strand-transfer inhibition of HIV integrase and anti-HIV activity. Bioorg. Med. Chem. Lett. 2007, 17, 1266-1269. [CrossRef]

182. Tashma, Z. N-alkyl thiocarbamoyl phosphonic acid esters-2. Alkylation by methyl iodide accompanied by phosphonate dealkylation. Tetrahedron 1982, 38, 3745-3747. [CrossRef]

183. Petneházy, I.; Szakál, G.; Tőke, L. Mono-dealkylation of phosphonic acid-esters and phosphoric-acid esters using halide-ions under phase-transfer conditions. Snythesis 1983, 6, 453-456. [CrossRef]

184. Krawczyk, H. A convenient route for monodealkylation of diethyl phosphonates. Synth. Commun. 1997, 27, 3151-3161. [CrossRef]

185. Chowdhury, S.; Muni, N.J.; Greenwood, N.P.; Pepperberg, D.R.; Standaert, R.F. Phosphonic acid analogs of GABA through reductive dealkylation of phosphonic diesters with lithium trialkylborohydrides. Bioorg. Med. Chem. Lett. 2007, 17, 3745-3748. [CrossRef] [PubMed]

186. Pardasani, D.; Purohit, A.; Kumar, A.; Tak, V.; Raghavender Goud, D.; Gupta, A.K.; Dubey, D.K. Synthesis of O-alkyl alkylphosphonates via hydrazine mediated partial dealkylation of phosphonate diesters. ChemistrySelect 2018, 3, 12312-12314. [CrossRef] 